\title{
Characterising mass-resolved mixing state of black carbon in Beijing using a morphology-independent measurement method
}

\author{
Chenjie Yu ${ }^{1}$, Dantong Liu ${ }^{2,1}$, Kurtis Broda ${ }^{3}$, Rutambhara Joshi ${ }^{1}$, Jason Olfert ${ }^{3}$, Yele Sun ${ }^{4}$, Pingqing Fu ${ }^{4, a}$, \\ Hugh Coe ${ }^{1}$, and James D. Allan ${ }^{1,5}$ \\ ${ }^{1}$ School of Earth and Environmental Sciences, University of Manchester, Manchester, M13 9PL, UK \\ ${ }^{2}$ Department of Atmospheric Sciences, School of Earth Sciences, Zhejiang University, Zhejiang, 310027, China \\ ${ }^{3}$ Department of Mechanical Engineering, University of Alberta, Alberta, T6G 2R3, Canada \\ ${ }^{4}$ Institute of Atmospheric Physics, Chinese Academy of Sciences, Beijing, 100029, China \\ ${ }^{5}$ National Centre for Atmospheric Sciences, University of Manchester, Manchester, M13 9PL, UK \\ ${ }^{a}$ now at: Institute of Surface-Earth System Science, Tianjin University, Tianjin, 300072, China
}

Correspondence: Dantong Liu (dantongliu@zju.edu.cn) and James Allan (james.allan@manchester.ac.uk)

Received: 3 May 2019 - Discussion started: 24 June 2019

Revised: 5 December 2019 - Accepted: 21 February 2020 - Published: 26 March 2020

\begin{abstract}
Refractory black carbon (rBC) in the atmosphere is known for its significant impacts on climate. The relationship between the microphysical and optical properties of rBC remains poorly understood and is influenced by its size and mixing state. Mixing state also influences its cloud scavenging potential and thus atmospheric lifetime. This study presents a coupling of a centrifugal particle mass analyser (CPMA) and a single-particle soot photometer (SP2) for the morphology-independent quantification of the mixing state of $\mathrm{rBC}$-containing particles, used in the urban site of Beijing as part of the Air Pollution and $\mathrm{Hu}$ man Health-Beijing (APHH-Beijing) project during winter (10 November-10 December 2016) and summer (18 May25 June 2017). This represents a highly dynamic polluted environment with a wide variety of conditions that could be considered representative of megacity area sources in Asia. An inversion method (used for the first time on atmospheric aerosols) is applied to the measurements to present two-variable distributions of both $\mathrm{rBC}$ mass and total mass of $\mathrm{rBC}$-containing particles and calculate the mass-resolved mixing state of $\mathrm{rBC}$-containing particles, using previously published metrics. The mass ratio between non-rBC material and $\mathrm{rBC}$ material (MR) is calculated to determine the thickness of a hypothetical coating if the $\mathrm{rBC}$ and other material followed a concentric sphere model (the equivalent coating thickness). The bulk MR (MR bulk $)$ was found to vary between 2 and 12 in winter and between 2 and 3 in summer.
\end{abstract}

This mass-resolved mixing state is used to derive the massweighted mixing state index for the $\mathrm{rBC}$-containing particles $\left(\chi_{\mathrm{rBC}}\right) \cdot \chi_{\mathrm{rBC}}$ quantifies how uniformly the non-rBC material is distributed across the $\mathrm{rBC}$-containing-particle population, with $100 \%$ representing uniform mixing. The $\chi_{\mathrm{rBC}}$ in Beijing varied between $55 \%$ and $70 \%$ in winter depending on the dominant air masses, and $\chi_{\mathrm{rBC}}$ was highly correlated with increased $\mathrm{MR}_{\text {bulk }}$ and $\mathrm{PM}_{1}$ mass concentration in winter, whereas $\chi_{\mathrm{rBC}}$ in summer varied significantly (ranging $60 \%-75 \%$ ) within the narrowly distributed $\mathrm{MR}_{\text {bulk }}$ and was found to be independent of air mass sources. In some model treatments, it is assumed that more atmospheric ageing causes the $\mathrm{BC}$ to tend towards a more homogeneous mixture, but this leads to the conclusion that the $\mathrm{MR}_{\text {bulk }}$ may only act as a predictor of $\chi_{\mathrm{rBC}}$ in winter. The particle morphologyindependent and mass-based information on $\mathrm{BC}$ mixing used in this and future studies can be applied to mixing-stateaware models investigating atmospheric $\mathrm{rBC}$ ageing.

\section{Introduction}

Black carbon (BC) is an important light-absorbing carbonaceous component of the atmospheric particulate matter and is regarded as dominant amongst absorbing aerosols in the atmosphere (Bond and Bergstrom, 2006). Atmospheric BC particles have both a direct positive impact and semidirect 
impact on Earth's radiative balance (Jacobson, 2000; Bond et al., 2013; IPCC, 2013). However, the climate impact of atmospheric BC particles contains large uncertainties (Ramanathan and Carmichael, 2008; Bond et al., 2013; Riemer et al., 2019). It is known that when BC is coated with other compounds the absorption will be enhanced due to the socalled "lensing effect" compared to the bare BC (Jacobson, 2001; Lack and Cappa, 2010), and the magnitude of coating thickness has a significant impact on the absorption properties of BC-containing particles (Moffet and Prather, 2009). However, the optical properties of BC-containing particles vary with $\mathrm{BC}$ mixing state, morphology and chemical compounds, which induces large uncertainties in the calculation of the BC absorption enhancement (Cappa et al., 2012; Liu et al., 2017). A number of observations (Cappa et al., 2012; Peng et al., 2016; Liu et al., 2017; Zhang et al., 2018b) and model studies (Wu et al., 2018; Zhang et al., 2018a) suggest that the absorption enhancement ranges from 1.0 up to 3.5. Though a number of different proposed model treatments give different predictions of BC mixing state (Jacobson, 2001; Murphy et al., 2006; Péré et al., 2009), none of these give perfect agreement with atmospheric observations, either in situ or remote (Fierce et al., 2016). As the coated $\mathrm{BC}$ particles may act as cloud condensation nuclei (CCN) in the atmosphere, the coating thickness information of $\mathrm{BC}$ containing particles can also influence the wet removal rate and thus its atmospheric lifetime and overall climate forcing potential (Kuwata et al., 2007; Schroder et al., 2015; Motos et al., 2019). Taylor et al. (2014) shows that the size distribution of BC-containing particles is important for the simulation of $\mathrm{BC}$ lifetime, vertical profile and transportation. The results from Liu et al. (2015) also show that the coating thickness of $\mathrm{BC}$ particles can largely influence their scavenging efficiency and lifetime in the clouds. The BC mixing state is especially important for polluted environments, where a combination of active sources, mixing and secondary aerosol formation mean that the $\mathrm{BC}$ mixing state is highly dynamic (Riemer et al., 2009). The mixing state of BC in most models remains unconstrained due to lack of measurement data, so this study aims to address this need by applying a new measurement technique to the atmosphere and offering new insight into the behaviour of $\mathrm{BC}$ in an important megacity.

To clearly quantify how well the $\mathrm{BC}$ particles are mixed in the atmosphere, the parameter "mixing state index" is applied for BC-containing particles in this study. Inspired by ecology studies (Whittaker, 1960, 1965), Riemer and West (2013) introduced a mathematical framework to quantify the aerosol mixing state. In this framework, the mixing state index $(\chi)$ is defined as the ratio between the average single-particle species diversity $\left(D_{\propto}\right)$ and the bulk particle species diversity $\left(D_{\gamma}\right)$, and the mixing state index $(\chi)$ varies from $0 \%$ (full external mixing; i.e. all particles consist of only one species which may be different for each particle) to $100 \%$ (full internal mixing; i.e. all particles are equally composed of all species). A number of measurement studies have generated this statistic by reporting a mass fraction of different compositions through various measurement techniques. Healy et al. (2014) reported that the variation of the bulk aerosols mixing state index in Paris winter is more related to the dominated air mass source by applying the single-particle aerosol mass spectrometer. Dickau et al. (2016) introduces a size and mass selection method to quantify the volatile mixing state of soot. As well as online measurements, offline microscopy techniques are also being used to retrieve species mass fractions. Bondy et al. (2018) performed a microscopy study on air samples collected from the south-eastern United States, and they found that most of the accumulation mode particles are internally mixed when the secondary organic aerosol concentration is high, and most of them are externally mixed during dust events. In this study, the mass-weighted mixing state index for $\mathrm{rBC}$-containing particles $\left(\chi_{\mathrm{rBC}}\right)$ is derived to investigate the distribution of non-rBC material across the rBC-containing-particle population in Beijing. As one of the large megacities in China, Beijing has suffered from heavy air pollution (Yang et al., 2005) and is likely to have many factors affecting $\mathrm{BC}$ mixing state, which in turn has implications for both air quality and climate (Ching and Kajino, 2018). These aerosols can have a global reach (Liu et al., 2015), and as their effects may be influenced by dynamic effects near the point of emission where concentrations are highest, a polluted urban environment represents a good location to investigate these behaviours and properties.

In this study, a coupled combination of a centrifugal particle mass analyser (CPMA, Cambustion Ltd., Cambridge, UK) and a single-particle soot photometer (SP2, DMT, Boulder, CO, USA) with a new inversion algorithm was applied in the field for the first time to characterise the mixing state of $\mathrm{rBC}$-containing particles in Beijing. In this context, the $\mathrm{BC}$ is referred to as "refractory black carbon" or rBC as an operational definition, consistent with Petzold et al. (2013). Liu et al. (2017) first introduced this morphology-independent instrument configuration to measure the mass ratio between non-rBC material and $\mathrm{rBC}$ material. Compared to the traditional SP2-only measurement, the significant improvement of the CPMA-SP2 method is that it can measure the non$\mathrm{rBC}$ material mass directly, which means no assumption is needed for non-rBC material density or its optical scattering behaviour. To clearly characterise the distribution of both $\mathrm{rBC}$ material and non-rBC material as part of a continuous scan (as opposed to discrete masses used previously by Liu et al., 2017), the CPMA-SP2 results are presented in a two-variable distribution by applying a novel inversion method presented by Broda et al. (2018). The concentric sphere equivalent coating thickness of rBC-containing particles and the non-rBC material distribution information across the $\mathrm{rBC}$-containing-particle population is derived from the measurement results, and the implication of these results is discussed. 


\section{Experiment details}

\subsection{APHH field campaign}

With the aim of identifying the mixing states of $\mathrm{rBC}$ in a complex urban environment, an experiment was devised as part of the Air Pollution and Human Health-Beijing (APHHBeijing) programme. The details of the wider campaign are described in Shi et al. (2019). The measurements were conducted during the APHH winter (10 November-10 December 2016) and summer (18 May-25 June 2017) intensive observation periods at the Institute of Atmospheric Physics (IAP) tower site. The site $\left(39^{\circ} 58^{\prime} 28^{\prime \prime} \mathrm{N}, 116^{\circ} 22^{\prime} 16^{\prime \prime} \mathrm{E}\right)$ is located in between the 3rd Ring Road and 4th Ring Road in the urban area of Beijing to the north of the city centre. As part of the AIRPRO and AIRPOLL joint campaign, these measurements also contribute to the better understanding of the critical pollutants and the pollution process in urban Beijing.

\subsection{Centrifugal particle mass analyser (CPMA)}

The CPMA sorts particles by their mass-to-charge ratio. The details of the CPMA have been described elsewhere (Olfert and Collings, 2005; Olfert et al., 2006). Briefly, two rotating coaxial cylindrical electrodes rotate at different angular velocities inside the CPMA. Particles of a narrow range of mass-to-charge ratio will exit the classifier based on a balance between electrostatic and centrifugal forces depending on the voltage difference between the electrodes and their rotational speed. The average mass of the particles $(m)$ exiting the CPMA is

$m=\frac{\phi e V}{\omega_{c}^{2} r_{c}^{2} \ln \left(\frac{r_{\mathrm{o}}}{r_{\mathrm{i}}}\right)}$,

where $e$ is the electronic charge $\left(1.6 \times 10^{-19} \mathrm{C}\right), \phi$ is number of charges carried by each particle, $V$ is the voltage difference, $r_{\mathrm{O}}$ is the outer cylinder radius, $r_{\mathrm{i}}$ is the inner cylinder radius and $\omega_{\mathrm{c}}$ is the rotation speed of the gas at the centre of the gap between the cylinders $r_{\mathrm{c}}\left(r_{\mathrm{c}}=\frac{1}{2}\left(r_{\mathrm{o}}+r_{\mathrm{i}}\right)\right)$. The charging in this instance was provided by a bipolar electrical neutraliser (MSP Corp., Shoreview, USA) that gives an equivalent charging profile to a traditional radioactive neutraliser for particles larger than $10 \mathrm{~nm}$. An additional bypass flow of $1 \mathrm{~L} \mathrm{~min}^{-1}$ was provided in addition to the $0.1 \mathrm{~L} \mathrm{~min}^{-1}$ sample flow of the SP2 to minimise diffusional losses through the neutraliser and tubing.

\subsection{Single-particle soot photometer (SP2)}

The SP2 is widely used in atmospheric rBC studies (Stephens et al., 2003). It consists of four optical detectors and one Nd:YAG crystal laser with a Gaussian intensity distribution (Schwarz et al., 2010). The SP2 can detect particles with an rBC component equivalent to a spherical diameter of 70$850 \mathrm{~nm}$ (Liu et al., 2010; Adachi et al., 2016). The details of the SP2 algorithm in Manchester are described in Liu et al. (2010) and McMeeking et al. (2010). The Manchester SP2 incandescence signal was calibrated using Aquadag black carbon particle standards (Aqueous Deflocculated Acheson Graphite, manufactured by Acheson Inc., USA) before the measurement, and the correction factor of 0.75 for ambient rBC measurement was applied (Laborde et al., 2012).

\subsection{Manchester CPMA-SP2 system}

A novel coupling measurement method, CPMA-SP2, has been applied to measure the non-rBC material mass among the population of $\mathrm{rBC}$ without morphology dependence (Liu et al., 2017). To set up the CPMA-SP2 system, the CPMA is placed upstream of the SP2 to classify particles of a nominal mass and sequentially pass these monodisperse particles to the SP2 for analysis of the mass of $\mathrm{rBC}$ from the individually classified particles. When sampling with the CPMASP2 system, the CPMA was set to select particles from 0.3 up to $\sim 15 \mathrm{fg}$. The CPMA performed one scan every $30 \mathrm{~min}$, and it took $\sim 20 \mathrm{~min}$ to complete one scan. For the remaining time, the CPMA rotation and voltage were disabled, meaning the SP2 was measuring the polydisperse aerosol measurement. A comparison between this and a bypassed configuration demonstrated that this introduced minimal losses. The CPMA-SP2 setup with mono-mass and polydispersed scan sequence is shown in Fig. S1 in the Supplement.

\subsection{NR-PM 1 (non-refractory particulate matter with aerodynamic diameter $<1 \mu \mathrm{m}$ ) measurement and back-trajectory model}

A high-resolution time-of-flight aerosol mass spectrometer (HR-ToF-AMS, Aerodyne Research Inc., USA) was used to measure the bulk aerosol non-refractory chemical compositions. The details of HR-ToF-AMS are described by DeCarlo et al. (2006). The mass concentration of the NR-PM (non-refractory particulate matter with aerodynamic diameter $<1 \mu \mathrm{m}$ ) particle is calculated from the sum of organics, sulfate, nitrate, ammonium and chloride.

The HYSPLIT back-trajectory model (Draxler and Hess, 1998) was run with the $1^{\circ} \times 1^{\circ}$ horizontal and vertical wind fields provided by the GDAS1 reanalysis meteorology data. The HYSPLIT model analysis was used to classify the sources of air mass that influenced the measurement site, and this method is described by Liu et al. (2018). As shown in Fig. 1, the continental air mass sources are classified into five regions: Northern Plateau, Southern Plateau, Western North China Plain (NCP) and Eastern NCP. 


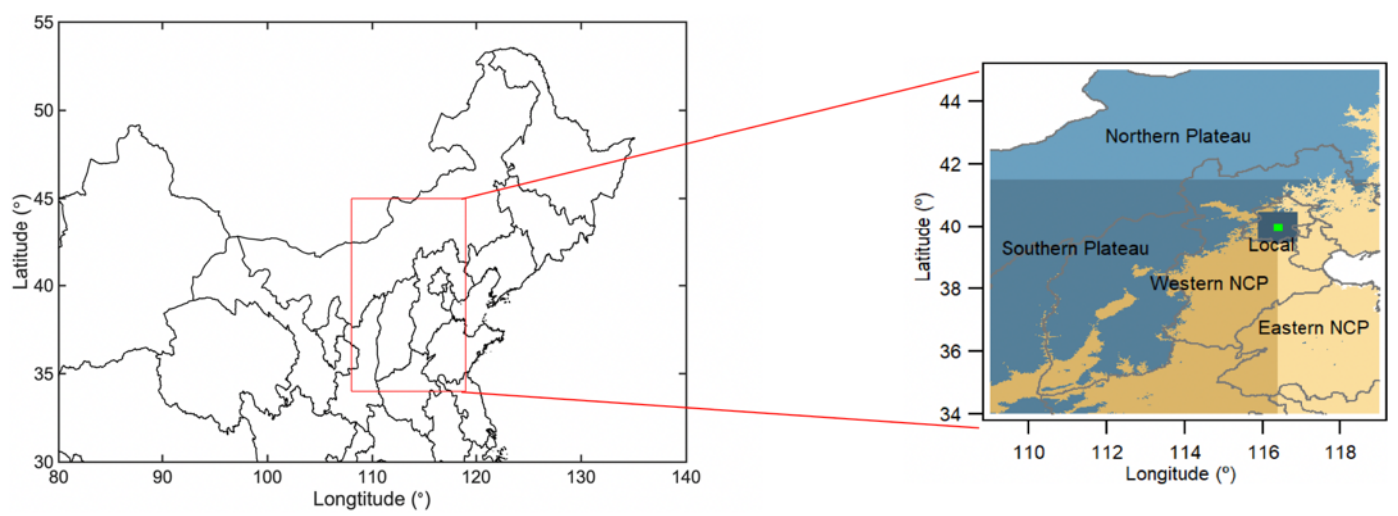

Figure 1. Classification of air mass sources (modified from Liu et al., 2019).

\section{Methods}

\subsection{CPMA-SP2 inversion}

To quantify the rBC mixing state in Beijing, the CPMASP2 results have been applied to a new inversion method introduced by Broda et al. (2018), according to the calculations described in the Supplement. The multiply charged particles are removed through the inversion process, and a two-variable distribution function is used to describe the distribution of the non-rBC material on the $\mathrm{rBC}$ particles:

$$
\frac{\partial^{2} N_{\mathrm{rBC}}}{\partial \log m_{\mathrm{p}} \partial \log m_{\mathrm{rBC}}},
$$

where $m_{\mathrm{p}}$ is the total mass of an individual $\mathrm{rBC}$-containing particle, and $m_{\mathrm{rBC}}$ is the mass of an individual $\mathrm{rBC}$ particle. $N_{\mathrm{rBC}}$ represents the number concentration of $\mathrm{rBC}$ containing particles with their total particle mass between $m_{\mathrm{p}}$ and $m_{\mathrm{p}}+\mathrm{d} m_{\mathrm{p}}$ and $\mathrm{rBC}$ particle mass between $m_{\mathrm{rBC}}$ and $m_{\mathrm{rBC}}+\mathrm{d} m_{\mathrm{rBC}}$. This two-variable distribution can also be integrated to single-variable number distributions $\left(\frac{\mathrm{d} N_{\mathrm{rBC}}}{\mathrm{d} \log m_{\mathrm{p}}}\right.$ and $\left.\frac{\mathrm{d} N_{\mathrm{rBC}}}{\mathrm{d} \log m_{\mathrm{rBC}}}\right)$ that are normally used in aerosol studies. An example of the original inverted two-dimensional distribution $\frac{\partial^{2} N_{\mathrm{rBC}}}{\partial \log m_{\mathrm{p}} \operatorname{\partial log} m_{\mathrm{rBC}}}$ graph retrieved from the measurement is presented in Fig. S2.

\subsection{Mixing state index of rBC-containing-particle calculation}

Riemer and West (2013) introduced the so-called "diversity parameters" to describe the particle mixing state. These parameters are based on the calculation of Shannon information entropy, which is often used to quantify uncertainties and is different from the thermodynamic entropy used in other areas (Shannon, 2001). The calculation process is described in Riemer and West (2013), and the necessary calculation process for the CPMA-SP2 results is described in the Supplement. In this study, each rBC-containing particle is consid- ered to contain two types of material: $\mathrm{rBC}$ material and non$\mathrm{rBC}$ material. The mass fractions of $\mathrm{rBC}$ material and non$\mathrm{rBC}$ material for each single $\mathrm{rBC}$-containing particle and the bulk rBC-containing-particle population that are used for the calculation are derived from the measured mass parameters. Briefly, the mixing state index for $\mathrm{rBC}$-containing particles $\left(\chi_{\mathrm{rBC}}\right)$ term can be given from

$\chi_{\mathrm{rBC}}=\frac{D_{\propto}-1}{D_{\gamma}-1}$,

where $D_{\alpha}$ and $D_{\gamma}$ represent the single-particle diversity and the bulk population diversity respectively and are used to describe the effective number of species in the single particle and the population of particles. The mass-weighted parameter $\chi_{\mathrm{rBC}}$ enables the precise quantification of the distribution of $\mathrm{rBC}$ material and non-rBC material mass fractions across the rBC-containing-particle population. For a wellmixed situation (all the $\mathrm{rBC}$-containing particles contain the same mass fraction of $\mathrm{rBC}$ material and non-rBC material), $D_{\gamma}=D_{\propto}=2$, and the mixing state index $\chi_{\mathrm{rBC}}=100 \%$. For a fully externally mixed situation (all the rBC-containing particles only contain the $\mathrm{rBC}$ material), $D_{i}=D_{\propto}=1$, and the mixing state index $\chi_{\mathrm{rBC}}$ will be undefined.

In this study, a high value of $\chi_{\mathrm{rBC}}$ means that all the rBCcontaining particles have the very similar $\mathrm{rBC}$ and non-rBC material mass fractions and is referred to as "even mixture", while a low value of $\chi_{\mathrm{rBC}}$ means the distribution of $\mathrm{rBC}$ and non-rBC material mass fractions is uneven across the rBCcontaining-particle population and is referred to as "uneven mixture".

\subsection{CPMA-SP2 two-variable distribution extrapolation}

As introduced in the previous section, the CPMA-SP2 system measurement range set for this measurement campaign is up to $m_{\mathrm{p}}=15 \mathrm{fg}$, which is roughly between 0.25 and $0.28 \mu \mathrm{m}$ in equivalent volume diameter for typical urban rBC-containing particles, based on studies in other cities. 
However, during certain periods throughout the winter campaign, the distribution unexpectedly extended to larger sizes outside of this range, meaning the overall $\mathrm{rBC}$ population was not completely captured by the measurement data. Some other studies regarding to the rBC-containing-particle size distribution in China (Gong et al., 2016; Wu et al., 2017; Zhang et al., 2018b) are in agreement that the volume diameter of rBC-containing particles is larger than the largest CPMA-selected size set in this study. To better quantify the bulk rBC mixing states and overcome the measurement range limitation, the number concentration of rBC-containing particles is extrapolated beyond the measurement range. From the previous CPMA-SP2 results by Liu et al. (2017), the number of distributions can be assumed as log-normal. Hence, the inversion results are extrapolated up to $m_{\mathrm{p}}$ around $300 \mathrm{fg}$, which is about $0.8 \mu \mathrm{m}$ in equivalent volume diameter, by fitting the measured results with the simulated distribution function, generated from the superposition of two log-normal distributions. Further details of the extrapolation process are presented in the Supplement. Briefly, the number distribution for $m_{\mathrm{p}}\left(\frac{\mathrm{d} N_{\mathrm{rBC}}}{\mathrm{d} \log m_{\mathrm{p}}}\right)$ is extrapolated based on the fitted distribution function. Two methods were then attempted to extrapolate the two-dimensional distribution $\frac{\partial^{2} N_{\mathrm{rBC}}}{\partial \log m_{\mathrm{p}} \partial \log m_{\mathrm{rBC}}}$ and critically compared with a view to determining the optimal method. One was based on fitting the two-variable distribution as a function of $m_{\mathrm{rBC}}$ (fit $m_{\mathrm{rBC}}$ method), and the other was based on fitting the two-variable distribution as a function of the mass ratio between the $m_{\mathrm{p}}$ and $m_{\mathrm{rBC}}$ (fit ratio method):

$$
\begin{aligned}
& \left.\frac{\partial^{2} N_{\mathrm{rBC}}}{\partial \log m_{\mathrm{p}} \partial \log m_{\mathrm{rBC}}}\right|_{\text {fit } m_{\mathrm{rBC},},(i, j)}= \\
& R_{i} \cdot\left(a_{1} \cdot \exp \left(-\left(\frac{\log \left(m_{\mathrm{rBC}, j}\right)-b_{1}}{c_{1}}\right)\right)\right. \\
& \left.+a_{2} \cdot \exp \left(-\left(\frac{\log \left(m_{\mathrm{rBC}, j}\right)-b_{2}}{c_{2}}\right)\right)\right) \text {, } \\
& \left.\frac{\partial^{2} N_{\mathrm{rBC}}}{\partial \log m_{\mathrm{p}} \partial \log m_{\mathrm{rBC}}}\right|_{\text {fit ratio, }(i, j)}= \\
& R_{i} \cdot\left(a_{1} \cdot \exp \left(-\left(\frac{\log \left(m_{\mathrm{p}, i} / m_{\mathrm{rBC}, j}\right)-b_{1}}{c_{1}}\right)\right)\right. \\
& \left.+a_{2} \cdot \exp \left(-\left(\frac{\log \left(m_{\mathrm{p}, i} / m_{\mathrm{rBC}, j}\right)-b_{2}}{c_{2}}\right)\right)\right) \text {, }
\end{aligned}
$$

while $\left.\frac{\partial^{2} N_{\mathrm{rBC}}}{\partial \log m_{\mathrm{p}} \partial \log m_{\mathrm{rBC}}}\right|_{(i, j)}$ represents the number concentration of the two-variable distribution at $m_{\mathrm{p}}$ bin $i$ and $m_{\mathrm{rBC}}$ bin $j ; R_{i}$ is the ratio between the rBC-containing-particle number concentration at the extrapolated $m_{\mathrm{p}}$ bin $i$ and the number concentration at the measured largest $m_{\mathrm{p}}$ bin (the bin with $\left.m_{\mathrm{p}}=15 \mathrm{fg}\right) ; a_{1}, b_{1}, c_{1}, a_{2}, b_{2}$ and $c_{2}$ are all the parameters for the distribution function.

To validate the reliability of the extrapolation, the total rBC mass concentration from the CPMA-SP2 extrapolations is compared with the SP2 data obtained during polydisperse sampling (shown in Fig. 2). For the polluted periods where large rBC-containing particles exist, the fit ratio method may overestimate the extrapolated $\mathrm{rBC}$ material size, and as a result, the extrapolated $\mathrm{rBC}$ mass is significantly higher than the SP2-only results for the polluted periods. The comparison of the fit ratio and fit $m_{\mathrm{rBC}}$ extrapolation methods shown in Fig. 2a illustrates that the fit $m_{\mathrm{rBC}}$ method is closer to the rBC mass concentration measured by the SP2-only method. For the summer results shown in Fig. 2b, the extrapolation results for the two methods are similar because the rBCcontaining particles were smaller and therefore the extrapolation was less necessary.

In general, the fit $m_{\mathrm{rBC}}$ method was found to better approximate the total $\mathrm{rBC}$ mass compared to the fit ratio method. Therefore, the results in this study are extrapolated by the fit $m_{\mathrm{rBC}}$ method.

\section{Results and discussion}

\subsection{APHH campaign overview and CPMA-SP2 two-variable distributions}

Figure 3 presents an overview of $\mathrm{rBC}$ and NR-PM 1 mass concentration for the whole winter and summer campaign. The $\mathrm{rBC}$ and NR-PM 1 mass concentration varied significantly in winter, and the $\mathrm{rBC}$ mass concentration increased to beyond $10 \mu \mathrm{g} \mathrm{m}^{-3}$, while the NR-PM 1 mass concentration increased above $300 \mu \mathrm{g} \mathrm{m}^{-3}$ during the polluted periods. In contrast, the $\mathrm{rBC}$ and $\mathrm{NR}-\mathrm{PM}_{1}$ mass concentration reduced significantly during the light-pollution periods. Compared to the winter periods, the rBC mass concentration varied less significantly in summer, and the peak of rBC mass concentration and NR-PM 1 mass concentration is lower. The $\mathrm{rBC}$ mass concentration reached a peak of around $4 \mu \mathrm{g} \mathrm{m}^{-3}$, while the NR-PM 1 mass concentration reached a peak of around $100 \mu \mathrm{g} \mathrm{m}^{-3}$.

Figure 4 shows the two-dimensional distribution $\partial^{2} N_{\mathrm{rBC}}$ $\frac{\partial^{2} N_{\mathrm{rBC}}}{\partial \log m_{\mathrm{p}} \partial \log m_{\mathrm{rBC}}}$ graph which presents the measured BC mixing state. To improve the signal-to-noise ratio of the data, the measured CPMA-SP2 data have been averaged over $3 \mathrm{~h}$ periods. According to the measurement results from winter campaign period, three types of mixing state distribution under three different pollution levels were observed, and these three types of pollution are heavy pollution $\left(\mathrm{NR}-\mathrm{PM}_{1}\right.$ greater than $\left.200 \mu \mathrm{g} \mathrm{m}^{-3}\right)$, moderate pollution $\left(\mathrm{NR}-\mathrm{PM}_{1}\right.$ between 100 and $200 \mu \mathrm{g} \mathrm{m}^{-3}$ ) and light pollution (NR-PM less than $100 \mathrm{\mu g} \mathrm{m}^{-3}$ ). These representative distributions under different pollution levels are shown in Fig. $4 \mathrm{a}-\mathrm{c}$. Figure $4 \mathrm{a}$ shows high concentrations of rBC-containing particles with both large $\mathrm{rBC}$ material and non-rBC material were observed under heavy haze (fog) pollution conditions in the morning of 4 December. During that day, a surface low pressure persisted in Beijing and its surrounding area, so air pollution accumulated to high concentrations. For the 


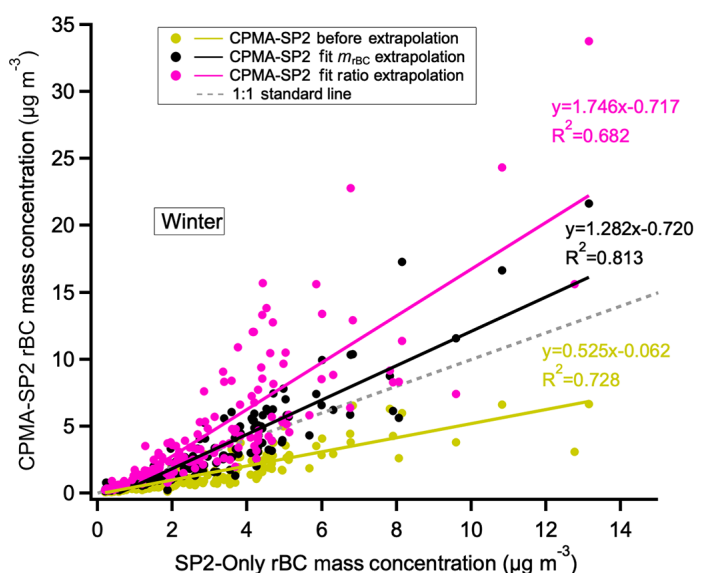

(a)

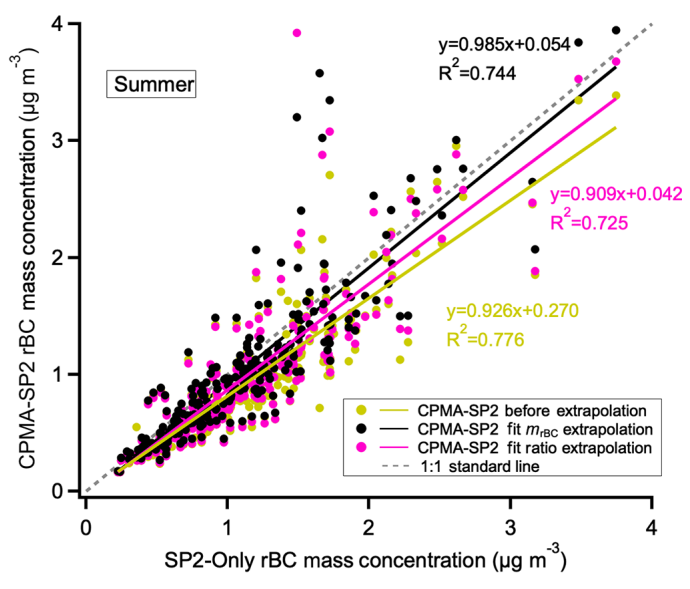

(b)

Figure 2. The rBC mass concentration comparison between the SP2-only measurement and two different CPMA-SP2 extrapolation methods in winter (a) and summer (b).

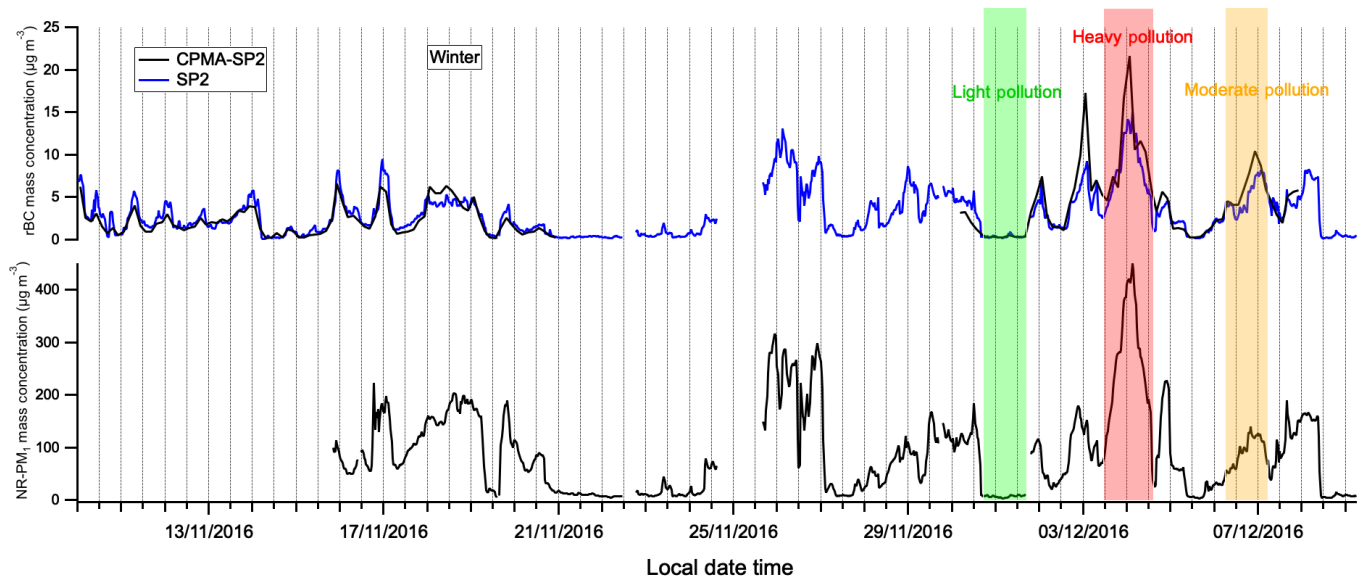

(a)
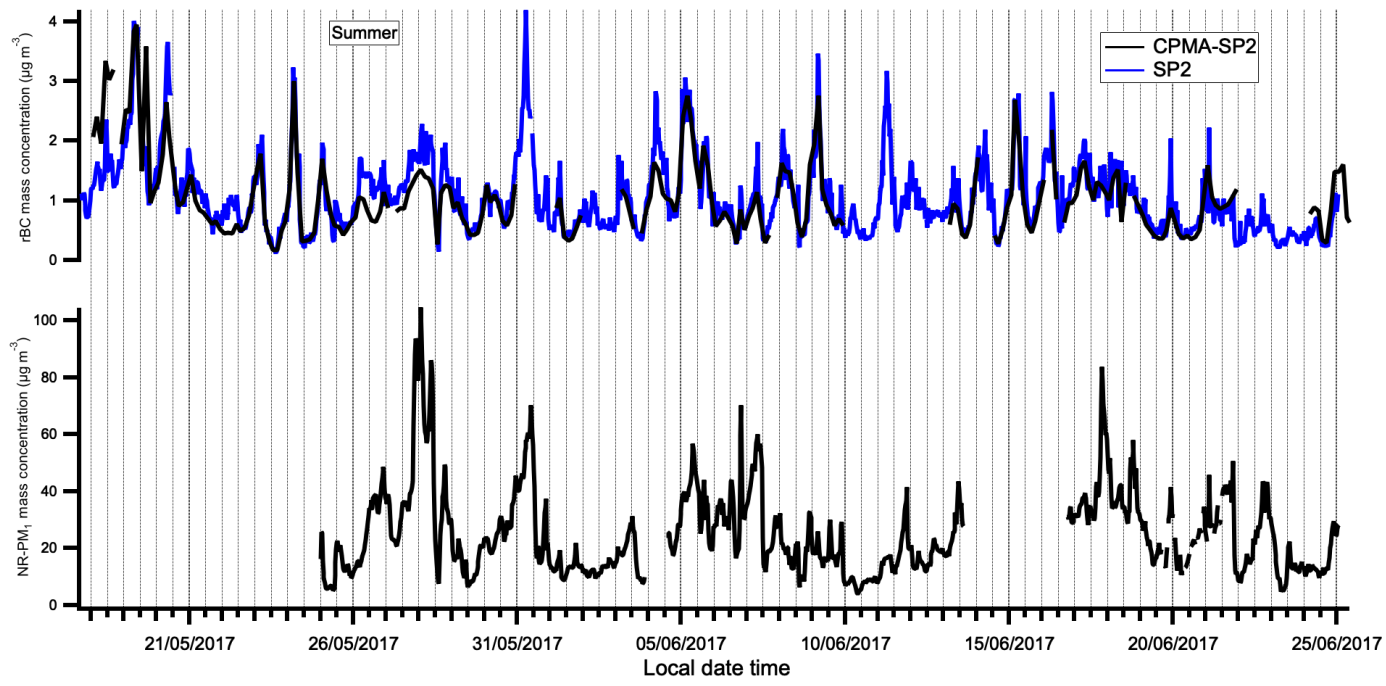

(b)

Figure 3. Time series of $\mathrm{rBC}$ mass concentration and NR-PM 1 concentration for the winter (a) and summer (b) campaign. 


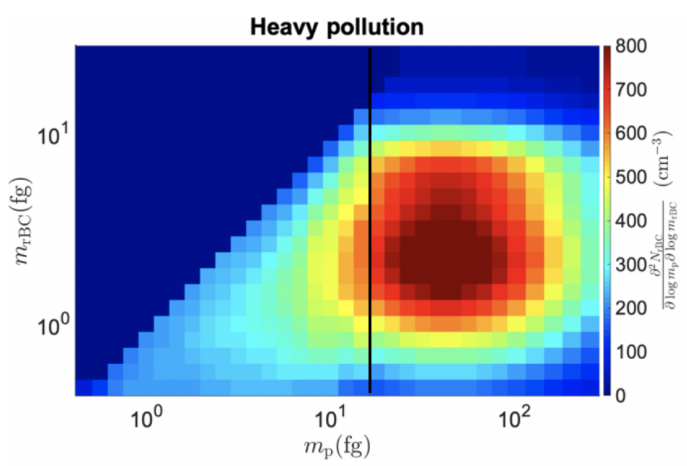

(a)

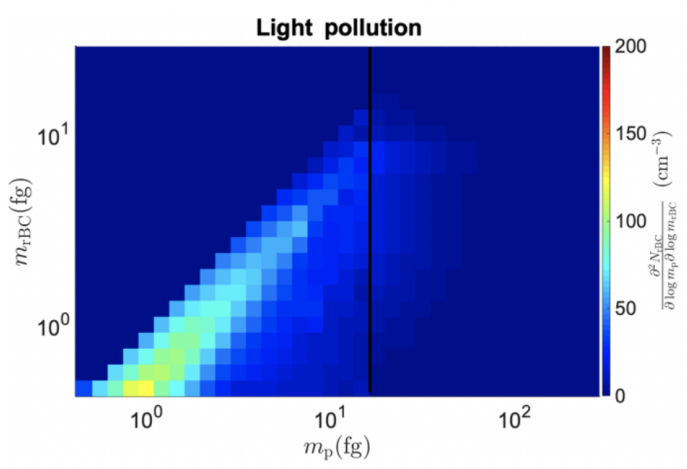

(c)

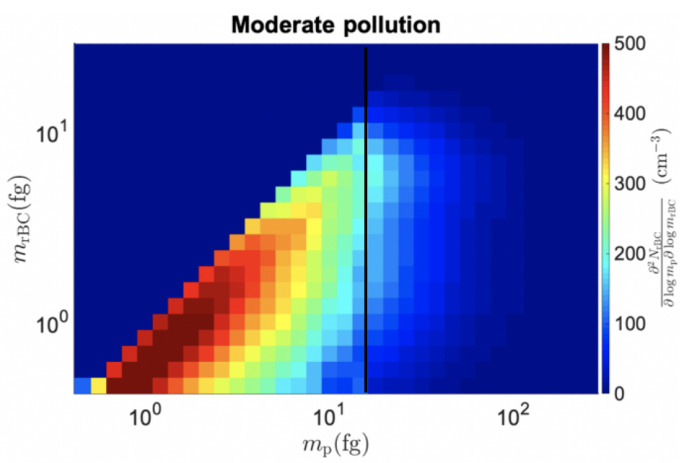

(b)

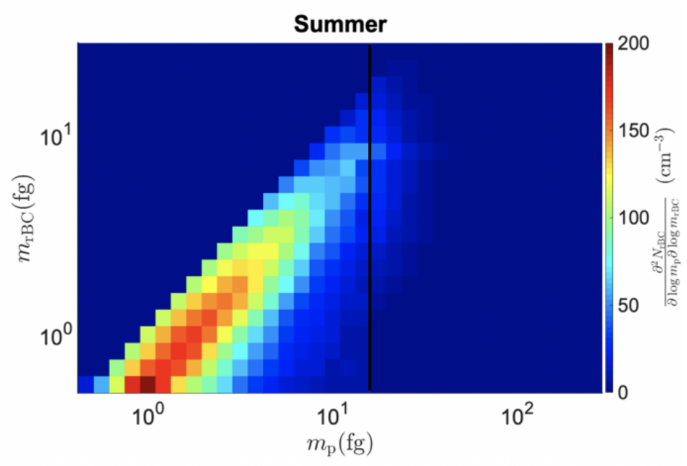

(d)

Figure 4. CPMA-SP2 inversion matrix examples under different pollution conditions in winter (a, b, c), and the example in the summer period (d); the $x$ axis, $m_{\mathrm{p}}$, represents the mass of the whole $\mathrm{rBC}$-containing particle, while the $y$ axis, $m_{\mathrm{rBC}}$, represents the mass of the $\mathrm{rBC}$ material. The colour bar represents the magnitude of the two-variable distribution with a number concentration unit of cubit centimetres $\left(\mathrm{cm}^{-3}\right)$. All the bins with $m_{\mathrm{rBC}}$ larger than $m_{\mathrm{p}}$ are zero since such a particle does not exist in reality, and therefore the two-dimensional function distribution graph has a triangle shape. The black solid line shows where the extrapolation starts.

moderate-pollution period shown in Fig. 4b, a large number of $\mathrm{rBC}$-containing particles with smaller amounts of $\mathrm{rBC}$ material and non-rBC material were observed. The period of light pollution shown in Fig. $4 \mathrm{c}$ has the smallest number concentration of $\mathrm{rBC}$-containing particles among all the three pollution types, but the shape of the two-variable distribution is similar to the moderate-pollution period in that most of the rBC-containing particles were smaller than $10 \mathrm{fg}$ and $\mathrm{rBC}$ particles with a relatively large non-rBC material fraction were rare. As no highly polluted events comparable to winter were observed in summer, the $\frac{\partial^{2} N_{\mathrm{rBC}}}{\partial \log m_{\mathrm{p}} \partial \log m_{\mathrm{rBC}}}$ distribution in summer does not show as much variation during the whole campaign period - one example is shown in Fig. 4d. It appears that the $\frac{\partial^{2} N_{\mathrm{rBC}}}{\partial \log m_{\mathrm{p}} \partial \log m_{\mathrm{rBC}}}$ distribution in summer is similar to the distribution for moderate- or light-pollution periods in winter.

The single-variable size distribution results from the integration of $\frac{\partial^{2} N_{\mathrm{rBC}}}{\partial \log m_{\mathrm{p}} \partial \log m_{\mathrm{rBC}}}$ are displayed in Fig. 5. The volume equivalent diameter for $\mathrm{rBC}$-containing particles $\left(D_{\mathrm{p}}\right)$ and the $\mathrm{rBC}$ material $\left(D_{\mathrm{c}}\right)$ is also calculated by assuming a density of $1.2 \mathrm{~g} \mathrm{~cm}^{-3}$ for $\mathrm{rBC}$-containing particles and a density of $1.8 \mathrm{~g} \mathrm{~cm}^{-3}$ for $\mathrm{rBC}$ material for better comparison with other studies based on aerodynamic diameter. For the $m_{\mathrm{p}}$ number concentration size distribution $\left(\frac{\mathrm{d} N_{\mathrm{rBC}}}{\mathrm{d} \log m_{\mathrm{p}}}\right)$ shown in Fig. 5a, the mode particle size is between 2 and $10 \mathrm{fg}$ for the light-pollution and moderate-pollution periods, while for the heavy-pollution period there is a large increase in the number concentration for $\mathrm{rBC}$-containing particles larger than $5 \mathrm{fg}$. The number concentration size distribution for the $m_{\mathrm{rBC}}\left(\frac{\mathrm{d} N_{\mathrm{rBC}}}{\mathrm{d} \log m_{\mathrm{rBC}}}\right)$ shown in Fig. 5b indicates that there is an increase in the number concentration for the $\mathrm{rBC}$-containing particles with relatively large $\mathrm{rBC}$ material (with $m_{\mathrm{rBC}}$ larger than $1 \mathrm{fg}$ ) during the heavy-pollution period in winter.

\subsection{Mass ratio between non-rBC material and rBC material}

The concentric sphere equivalent coating thickness information is presented through the mass ratio (MR) parameter which is derived from the CPMA-SP2 inversion results. The MR parameter defined here follows the definition of Liu et 


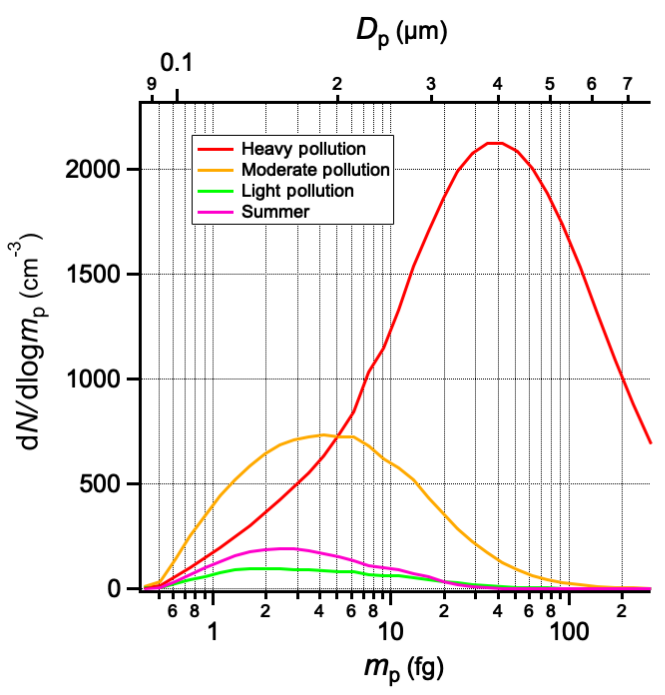

(a)

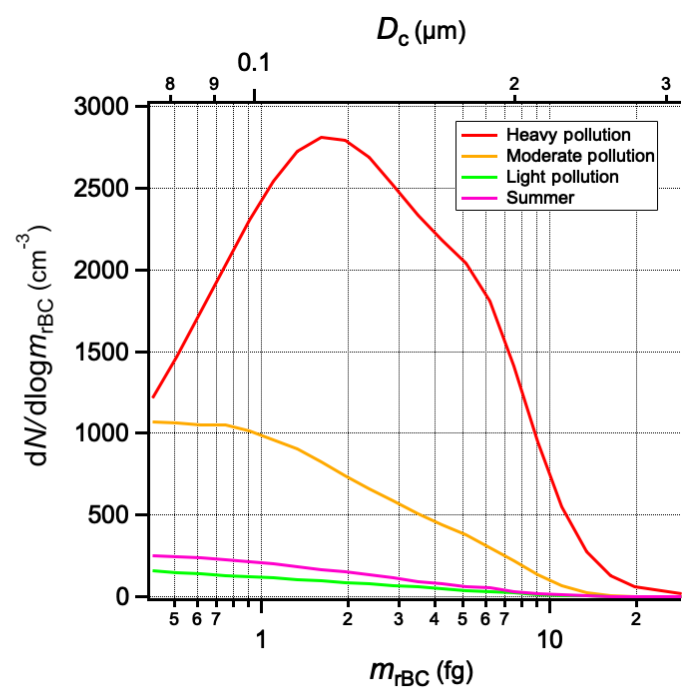

(b)

Figure 5. CPMA-SP2 $m_{\mathrm{p}}$ number distribution (a) and $m_{\mathrm{rBC}}$ number distribution (b) under different pollution conditions.

al. (2017), which is given by

$\mathrm{MR}_{i}=\frac{m_{\mathrm{non}-\mathrm{BC}, i}}{m_{\mathrm{rBC}, i}}=\frac{m_{\mathrm{p}, i}-m_{\mathrm{rBC}, i}}{m_{\mathrm{rBC}, i}}$,

where $\mathrm{MR}_{i}$ is the mass ratio for $\mathrm{rBC}$-containing particle $i, m_{\text {non-rBC }}$ is the non-rBC material within $\mathrm{rBC}$-containing particle $i$, and $m_{\mathrm{p}, i}$ and $m_{\mathrm{rBC}, i}$ are the mass of the $\mathrm{rBC}$ containing particle $i$ and the mass of the $\mathrm{rBC}$ material for rBC-containing particle $i$ respectively. The traditional SP2only method calculates MR by applying measured optical properties through the leading edge only (LEO) technique, and assumptions regarding the refractive indices and morphology are needed to determine the bulk concentric sphere equivalent coating thickness (Gao et al., 2007; Liu et al., 2014; Broda et al., 2018). The CPMA-SP2 method, however, is able to quantify the mass parameters more directly and without LEO fitting or a scattering inversion; therefore, the MR measured by CPMA-SP2 can be considered to be much more accurate. The bulk MR ( $\left.\mathrm{MR}_{\text {bulk }}\right)$ measured by CPMA-SP2 is calculated as follows:

$$
\begin{aligned}
\mathrm{MR}_{\mathrm{bulk}} & =\frac{\int \frac{\mathrm{d} M_{\mathrm{p}}}{\mathrm{d} \log m_{\mathrm{p}}} \mathrm{d} \log m_{\mathrm{p}}}{\int \frac{\mathrm{d} M_{\mathrm{rBC}}}{\mathrm{d} \log m_{\mathrm{rBC}}} \mathrm{d} \log m_{\mathrm{rBC}}} \\
& =\frac{\iint \frac{\partial^{2} N_{\mathrm{rBC}}}{\partial \log m_{\mathrm{p}} \partial \log m_{\mathrm{rBC}}} m_{\mathrm{p}} \mathrm{d} \log m_{\mathrm{rBC}} \mathrm{d} \log m_{\mathrm{p}}}{\iint \frac{\partial^{2} N_{\mathrm{rBC}}}{\partial \log m_{\mathrm{p}} \partial \log m_{\mathrm{rBC}}} m_{\mathrm{rBC}} \mathrm{d} \log m_{\mathrm{rBC}} \mathrm{d} \log m_{\mathrm{p}}}-1,
\end{aligned}
$$

where $M_{\mathrm{p}}$ and $M_{\mathrm{rBC}}$ are the total mass concentration for $\mathrm{rBC}$ containing particles and $\mathrm{rBC}$ particles respectively. The comparison between $\mathrm{MR}_{\text {bulk }}$ from the CPMA-SP2 method and the SP2-only method is shown in Fig. 6. The MR bulk from the SP2-only method is derived by applying the SP2 LEO fitting method to $\mathrm{rBC}$-containing particles with $D_{\mathrm{p}}$ in the range

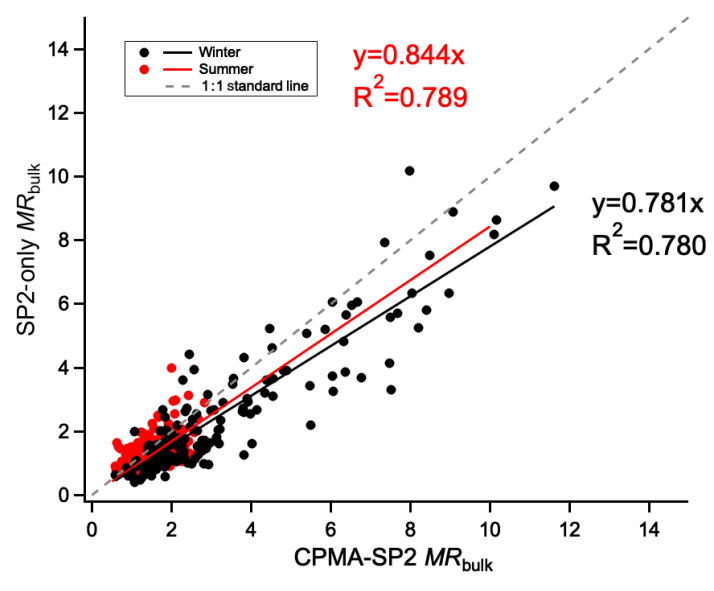

Figure 6. The comparison between bulk mass ratio $\left(\mathrm{MR}_{\text {bulk }}\right)$ from the CPMA-SP2 method and from the SP2-only method.

of $0.08-0.8 \mu \mathrm{m}$ and $D_{\mathrm{c}}$ in the range of $0.08-0.55 \mu \mathrm{m}$. The $\mathrm{MR}_{\text {bulk }}$ from the CPMA-SP2 method shows a good correlation with the SP2-only method during the summer period and the winter period. Despite a slight lower $\mathrm{MR}_{\text {bulk }}$ observed from the SP2-only method, the $\mathrm{MR}_{\text {bulk }}$ results from the two methods are generally close.

The CPMA-SP2 MR bulk time series for winter and summer are presented in Fig. 7. A significant increase was observed during the winter heavy-pollution period, and the $\mathrm{MR}_{\text {bulk }}$ reached a maximum of 10 on 4 December. During low pollution periods the $\mathrm{rBC}$ particles had a lower $\mathrm{MR}_{\text {bulk }}$ around 2. According to the source apportionment work during the same study by Liu et al. (2019) and Wang et al. (2019), around $64 \%$ of organic components within the rBC-containing particles were from primary sources in win- 

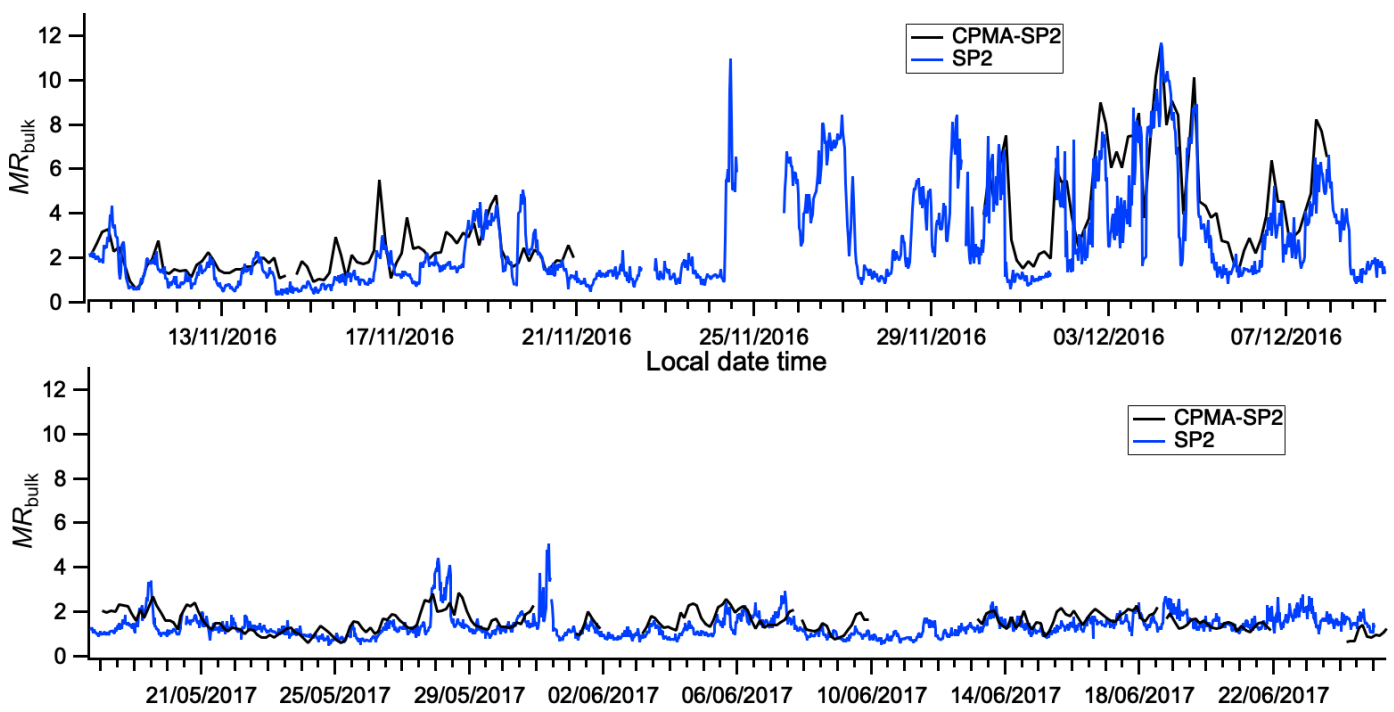

Local date time

Figure 7. Time series of $\mathrm{MR}_{\mathrm{bulk}}$ for winter and summer.

ter. These sources may also emit non-rBC material externally mixed with $r B C$. During the heavy-pollution period in winter, a significant enhancement of secondary organic aerosol was observed (Wang et al., 2019). Figure 4 showed that, during the highly polluted period, there were large numbers of $\mathrm{rBC}$ containing particles with $m_{\mathrm{rBC}}$ between 1 and $10 \mathrm{fg}$. These rBC-containing particles with large $m_{\mathrm{rBC}}$ mostly originated from the Southern Plateau based on the back-trajectory analysis in Fig. 10a, and Liu et al. (2019) suggested that they may be from coal burning. High pollution tends to introduce increased concentrations of gas precursors promoting the condensation of secondary material, and the higher overall particulate concentration promotes coagulation, particularly at the top of the boundary layer where the high humidity causes particles to grow further. Both condensation and coagulation will lead to more efficient mixing of $\mathrm{rBC}$ and increased $\mathrm{MR}_{\text {bulk. }}$. In contrast, during the lightly polluted periods, the fractions of non-rBC material within the $\mathrm{rBC}$ containing-particle population were much lower. The relatively cleaner air masses from the Northern Plateau dominated most of the light-pollution periods (Liu et al., 2019). With the absence of high absolute non-rBC material concentrations, the rBC-containing particles were externally mixed or had a lower fraction of non-rBC material.

Figure 7 shows that the $\mathrm{MR}_{\text {bulk }}$ in summer varied between 1 and 2.7 with several moderate $\mathrm{MR}_{\text {bulk values }}\left(\mathrm{MR}_{\text {bulk }}>2\right)$, which was generally lower than in winter. Compared to the winter periods, the source apportionment shows that secondary material contributed more to the total organic aerosol species within the rBC-containing particles (Xie et al., 2019; Wang et al., 2019).

The $\mathrm{MR}_{\text {bulk }}$ frequency distribution is presented in Fig. 8 . Most of the rBC-containing particles contained a small frac-

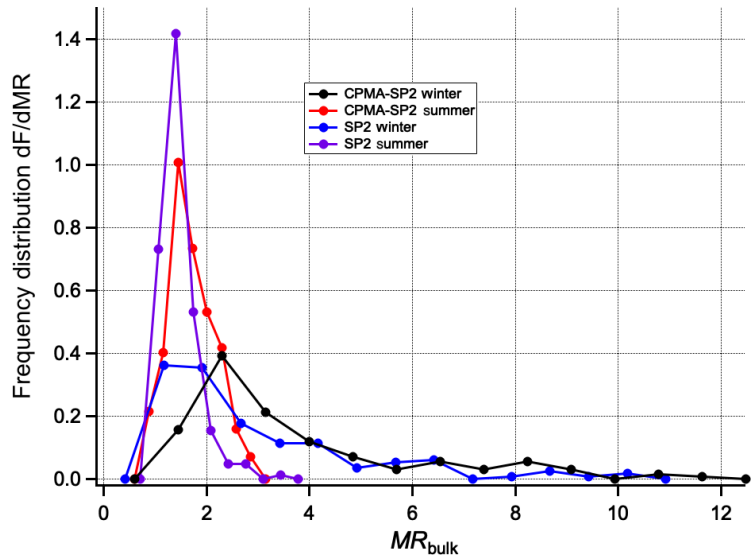

Figure 8. Frequency distribution of $\mathrm{MR}_{\text {bulk }}$ from both the CPMASP2 and SP2-only method.

tion of non-rBC material with the $\mathrm{MR}_{\text {bulk }}$ less than 2 in both winter and summer. The range of $\mathrm{MR}_{\text {bulk }}$ values was also much broader in winter compared to the summer period. Some rBC-containing particles containing a large fraction of non-rBC material $\left(\mathrm{MR}_{\text {bulk }}>3\right)$ were observed in winter, while no such particles were found during the summer period. In general, the $\mathrm{MR}_{\text {bulk }}$ frequency distribution from the CPMA-SP2 and SP2-only methods is similar.

A CPMA-SP2 two-variable distribution is able to present detailed single $\mathrm{rBC}$-containing-particle concentric sphere equivalent coating thickness information. The $\mathrm{MR}_{i}$ can be derived to quantify the concentric sphere equivalent coating thickness on each rBC-containing particle. Liu et al. (2017) stated that $\mathrm{rBC}$-containing particles with $\mathrm{MR}_{i}$ lower than 1.5 are typical for traffic emissions, while an MR greater than 3 
is typical for biomass burning emissions. The rBC mass fraction under different $\mathrm{MR}_{i}$ level classifications is presented in Fig. 9. Comparing the summer results with the winter results, the fraction of $\mathrm{rBC}$-containing particles with a tiny fraction of non-rBC material $\left(\mathrm{MR}_{i} \sim 0\right)$ and $\mathrm{rBC}$-containing particles with a moderate fraction of non-rBC material $(1.5 \leq$ $\left.\mathrm{MR}_{i}<3\right)$ is similar. The mass fraction varied slightly around $20 \%$ for uncoated rBC-containing particles at both summer and winter campaign periods. The $\mathrm{rBC}$-containing particles with a large fraction of non-rBC material $\left(\mathrm{MR}_{i} \geq 3\right)$ accounted for a higher fraction in winter, especially for the heavy-haze periods between 3 and 5 December. The significant enhancement of the fraction of $\mathrm{rBC}$-containing particles with $\mathrm{MR}_{i} \geq 3$ was more likely related to the increase in the fraction of secondary components during the heavily polluted period in winter (Wang et al., 2019). The rBCcontaining particles with a small fraction of non-rBC material $\left(0<\mathrm{MR}_{i}<1.5\right)$ accounted for a large portion (around $60 \%$ ) during the light-pollution periods in winter and occurred most of the time in summer. These rBC-containing particles with much lower $\mathrm{MR}_{i}$ were likely to be generated from the consumption of fossil fuels (Liu et al., 2017, 2019).

\subsection{Entropy parameters and $\mathrm{rBC}$ mixing state}

Derived from the CPMA-SP2 inversions, the bulk diversity $\left(D_{\gamma}\right)$ and the mixing state index for rBC-containing particles $\left(\chi_{\mathrm{rBC}}\right)$ results shown in Fig. 10 illustrate the variation of $\mathrm{BC}$ mixing state for the whole APHH campaign period. As the CPMA-SP2 system only detects the rBC-containing particles, the number of species set here is two: the $\mathrm{rBC}$ and non-rBC material. To reiterate, this metric should be taken as the level of homogeneity of $\mathrm{rBC}$ mixing state amongst the rBC-containing particles.

$\chi_{\mathrm{rBC}}$ varied around $62 \%$ between 10 and 21 November. A decrease in $\chi_{\mathrm{rBC}}$ was observed between 19 and 20 December, which indicates a period of more externally mixed rBC. Apart from some minor $\chi_{\mathrm{rBC}}$ spikes, the mixing state of $\mathrm{rBC}$-containing particles remained unchanged between 10 and 21 November, whereas for the results between 1 and 6 December, $\chi_{\mathrm{rBC}}$ and $D_{\gamma}$ varied dramatically. After the polluted period on 30 November, a light-pollution period occurred on 1 December and $\chi_{\mathrm{rBC}}$ decreased rapidly to below $60 \%$. When the haze formed between 2 and 4 December, $\chi_{\mathrm{rBC}}$ increased gradually. In contrast, $D_{\gamma}$ decreased significantly during this heavy-pollution period which was mainly caused by the thick non-rBC material on the $\mathrm{rBC}$ material, leading to a reduction of $\mathrm{rBC}$ material mass fraction percentage. The haze subsided after $\chi_{\mathrm{rBC}}$ reached the peak of around $70 \%$ on 4 December, another light-pollution period appeared, and $\chi_{\mathrm{rBC}}$ and $D_{\gamma}$ resumed to the value before the haze. For the moderate-pollution period between 6 and 7 December, $\chi_{\mathrm{rBC}}$ reached another peak of around $68 \%$, and the increase in $\mathrm{MR}_{\text {bulk }}$ led $D_{\gamma}$ to decrease to around 1.5.
To investigate the mixing state of smaller $\mathrm{rBC}$-containing particles, the mixing state index at smaller $m_{\mathrm{p}}$ is also calculated, shown in Fig. 10. The $\chi_{\mathrm{rBC}}$ at $m_{\mathrm{p}} \leq 15$ and $m_{\mathrm{p}} \leq 5 \mathrm{fg}$ is shown to be higher than the bulk $\chi_{\mathrm{rBC}}$, indicating that the $\mathrm{rBC}$ material was more evenly distributed among rBCcontaining particles at smaller sizes. For most of the winter period, the trend of $\chi_{\mathrm{rBC}}$ at $m_{\mathrm{p}} \leq 15$ and $m_{\mathrm{p}} \leq 5$ fg was similar to the trend of bulk $\chi_{\mathrm{rBC}}$. However, during the heavypollution period between 3 and 4 December, the $\chi_{\mathrm{rBC}}$ at $m_{\mathrm{p}} \leq 5 \mathrm{fg}$ decreased slightly, suggesting that there was a relatively uneven distribution of $\mathrm{rBC}$ material and non-rBC material mass fractions for the smaller $\mathrm{rBC}$-containing particles. During summer, the $\chi_{\mathrm{rBC}}$ at $m_{\mathrm{p}} \leq 15 \mathrm{fg}$ and $m_{\mathrm{p}} \leq 5 \mathrm{fg}$ was closer to the bulk $\chi_{\mathrm{rBC}}$ because of $\mathrm{rBC}$-containing particles in summer being smaller and most of the $\mathrm{rBC}$-containing particles having smaller $\mathrm{MR}_{i}$.

The mixing state of rBC-containing particles can be also associated with the air mass sources, and the relationship between the major air mass source, MR and $\mathrm{rBC}$ mixing state is further explored further in Fig. 11. The winter characterisation result is shown in Figs. 10a and 11a. Among all the air mass sources, Plateau South and Western NCP were considered to represent the polluted air masses from which aged $\mathrm{rBC}$-containing particles with larger $\mathrm{MR}_{i}$ were transported during this period. When higher $\chi_{\mathrm{rBC}}$ (between $60 \%$ and $75 \%$ ) and $\mathrm{MR}_{\text {bulk }}$ values (between 2 and 12) were observed the Plateau South air mass periods dominated. When local air mass and Plateau North air mass accounted for more fractions, the presences of $\mathrm{rBC}$-containing particles with smaller $\mathrm{MR}_{i}$ contributed to the significant increase in $D_{\gamma}$ values and rapid decrease in $\chi_{\mathrm{rBC}}$ and $\mathrm{MR}_{\text {bulk }}$ values. For example, the reduction of $\mathrm{rBC}$-containing-particle internal mixture on 30 November and 5 December can be associated with a relative clean Plateau North air mass. This evolution during the winter period agrees with the findings from Paris of Healy et al. (2014), who found that when considering the mixing state of bulk aerosol mass (which considered multiple non$\mathrm{rBC}$ species) there was a trend towards more homogenous mixing when polluted air masses dominate compared to the local and clean marine air mass periods.

For the summer period shown in Fig. $10 \mathrm{~b}, \chi_{\mathrm{rBC}}$ varied between $60 \%$ and $75 \%$. As the $\mathrm{MR}_{\text {bulk }}$ was lower in summer, the mass fraction of $\mathrm{rBC}$ material and the mass fraction of non-rBC material was closer within the bulk population, hence a slightly higher $D_{\gamma}$ was observed in summer. Though the $\mathrm{MR}_{\text {bulk }}$ and the $\mathrm{rBC}$ mass concentration was not as high as that in winter, sharp decreases in $D_{\gamma}$ together with the increase in $\chi_{\mathrm{rBC}}$ still occurred occasionally in summer, which indicate that some $\mathrm{rBC}$-containing particles with moderate non-rBC material were observed. Unlike the winter campaign period, the back-trajectory results in summer shown in Fig. 11b do not show a significant association between mixing state parameters and air mass origin. 

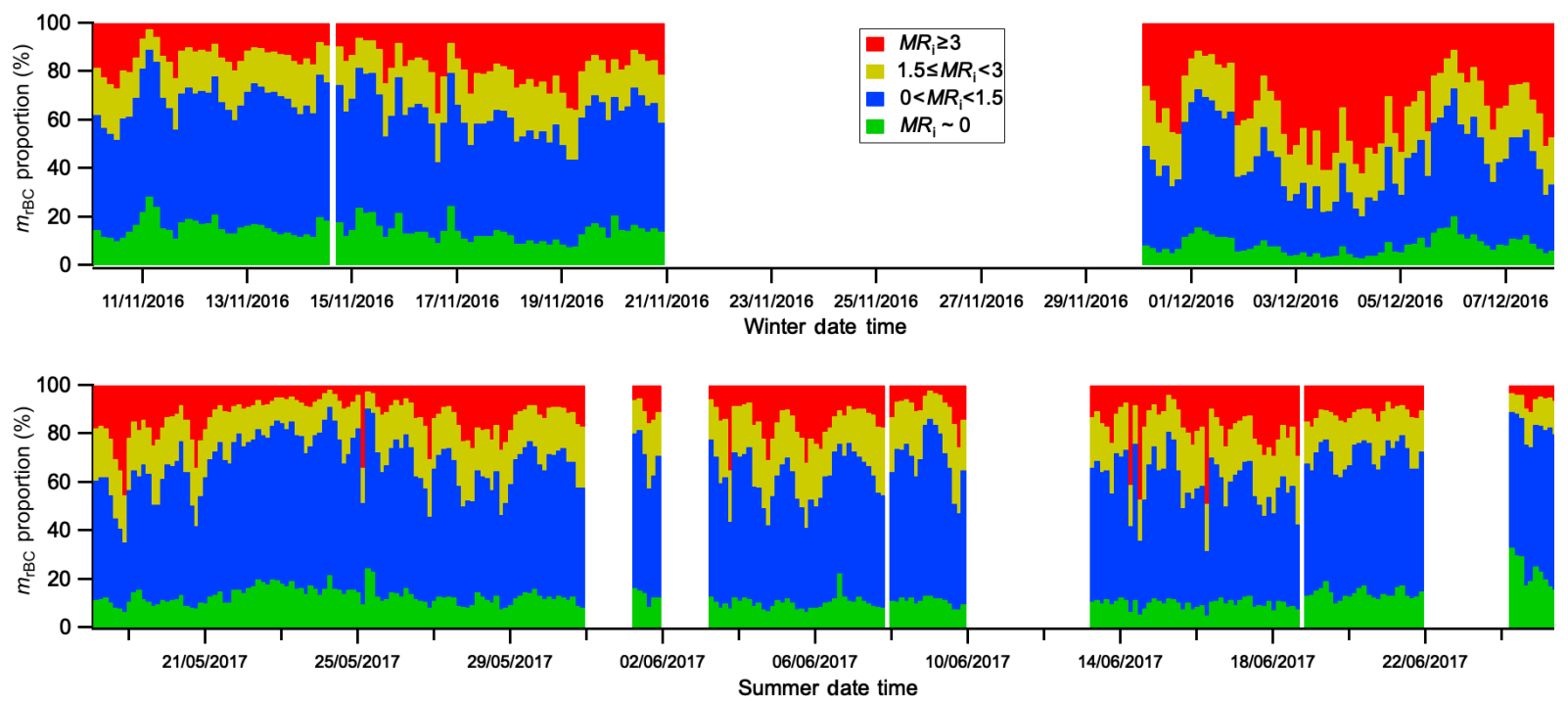

Figure 9. The evolution of rBC material mass fraction at a different single-particle $\mathrm{MR}\left(\mathrm{MR}_{i}\right)$ level for winter and summer.

\subsection{Discussion}

In order to investigate which other parameters may act as a predictor for mixing state, Fig. 12 shows the variation of $\chi_{\mathrm{rBC}}$ in both summer and winter against (a) NR-PM 1 and $\mathrm{rBC}$ mass concentration and (b) $\mathrm{MR}_{\text {bulk. }}$. There was a positive correlation between the variation of $\chi_{\mathrm{rBC}}$ and the variation of $\mathrm{MR}_{\text {bulk }}$ in winter as $\mathrm{rBC}$-containing particles with larger non$\mathrm{rBC}$ material (larger $\mathrm{MR}_{\text {bulk }}$ ) tended to exhibit a more even mixture during the winter campaign period. For the summer period, no such positive correlation was found. Although the rBC-containing particles did not contain a large fraction of non-rBC material in summer, and the pollution level was lower, there was significant variation of $\chi_{\mathrm{rBC}}$, which indicates that the distribution of $\mathrm{rBC}$ and non-rBC material mass fractions among the $\mathrm{rBC}$-containing particles varies in a narrow range of lower $\mathrm{MR}_{\text {bulk }}$. This indicates that higher $\mathrm{MR}_{\text {bulk }}$ can be related to increased levels of a more even mixture of rBC-containing particles in winter, while the $\mathrm{MR}_{\text {bulk }}$ metric cannot be used to predict the variation of $\chi_{\mathrm{rBC}}$ in summer.

Comparing the two seasons, there was more diversity in the distribution of $\mathrm{rBC}$ mixing state in summer than in winter under similar $\mathrm{MR}_{\text {bulk }}$ or similar NR-PM 1 and $\mathrm{rBC}$ mass concentrations. About $30 \%$ of the experimental period in summer had $\chi_{\mathrm{rBC}}$ over $70 \%$; however, this fraction was almost absent in winter. This means that although the pollution was low in summer, a more homogenous distribution of non-rBC material was present.

As $\chi_{\mathrm{rBC}}$ is a mass-weighted parameter, it is dominated by the larger $\mathrm{rBC}$-containing particles. During the heavypollution period in winter, there was generally more particulate matter, so the non-rBC materials have a higher probability of coagulating with or condensing on primary $\mathrm{rBC}$, resulting in the relatively higher amount of non-rBC mate- rial detected in winter. The $\mathrm{rBC}$ particles with a higher $\mathrm{MR}_{i}$ contributed most to the $\mathrm{rBC}$ mass concentration during the heavy-pollution periods (shown in Fig. 9), and the fraction of the secondary non-rBC material within $\mathrm{rBC}$-containing particles increased with pollution level (Wang et al., 2019). These large $\mathrm{rBC}$-containing particles with a large fraction of non-rBC material dominated the total $\mathrm{rBC}$-containingparticle mass and showed a higher $\chi_{\mathrm{rBC}}$ value. This increasing trend of $\chi_{\mathrm{rBC}}$ was shown to correspond to the $\mathrm{MR}_{\text {bulk }}$ and NR-PM 1 level, and this means the higher pollution will be associated with enhanced non-rBC material and a similar mixing state for most $\mathrm{rBC}$-containing particles in winter.

During the lighter-pollution periods, most of the $\mathrm{rBC}$ containing particles had a lower $\mathrm{MR}_{i}$, and a lower $\mathrm{MR}_{\text {bulk }}$ was present. A lower $\chi_{\mathrm{rBC}}$ was present when $\mathrm{MR}_{\text {bulk }}$ or the pollution level was lower in winter. One reason is that although the $\mathrm{MR}_{\text {bulk }}$ is lower, there were still some relatively large $\mathrm{rBC}$-containing particles with a large or moderate $\mathrm{MR}_{i}$, which were not sufficient to dominate the overall $\mathrm{rBC}$ containing-particle mass concentration or overall $\chi_{\mathrm{rBC}}$ during the light-pollution periods. A significant difference was thus observed between the $\chi_{\mathrm{rBC}}$ for small $\mathrm{rBC}$-containing particles (at $m_{\mathrm{p}} \leq 5 \mathrm{fg}$ ) and the bulk $\chi_{\mathrm{rBC}}$. The other reason for the uneven distribution of non-rBC material and $\mathrm{rBC}$ material mass fractions may be that the appearance of non-rBC material in $\mathrm{rBC}$-containing particles is being limited. There were more $\mathrm{rBC}$-containing particles with little non-rBC material during this period, compared to the moderate- or heavypollution periods in winter. Therefore, the non-rBC material and $\mathrm{rBC}$ material mass fractions tended to be unevenly distributed among $\mathrm{rBC}$-containing particles, and the $\chi_{\mathrm{rBC}}$ shows a lower value.

As there were fewer large $\mathrm{rBC}$-containing particles in summer, the bulk $\chi_{\mathrm{rBC}}$ result is close to the $\chi_{\mathrm{rBC}}$ result of 


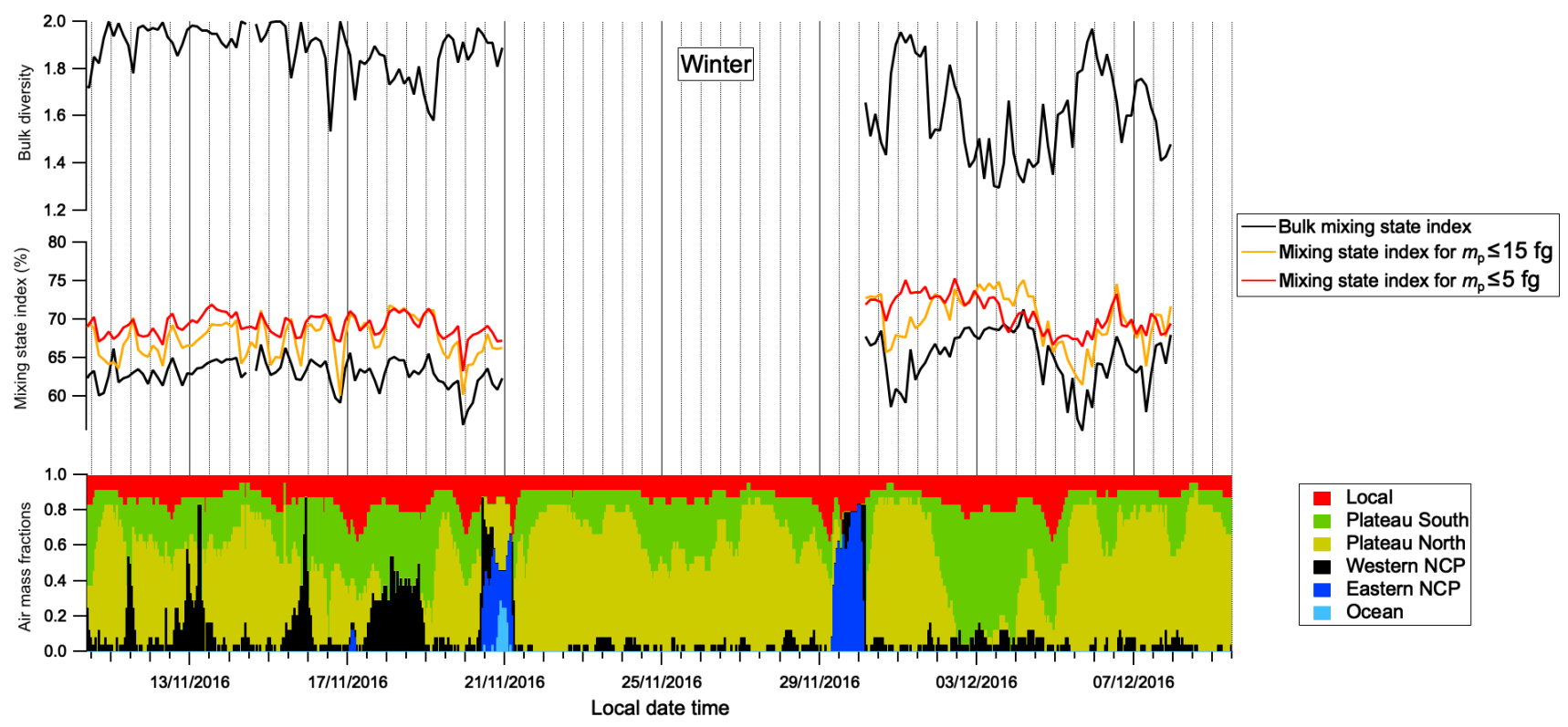

(a)

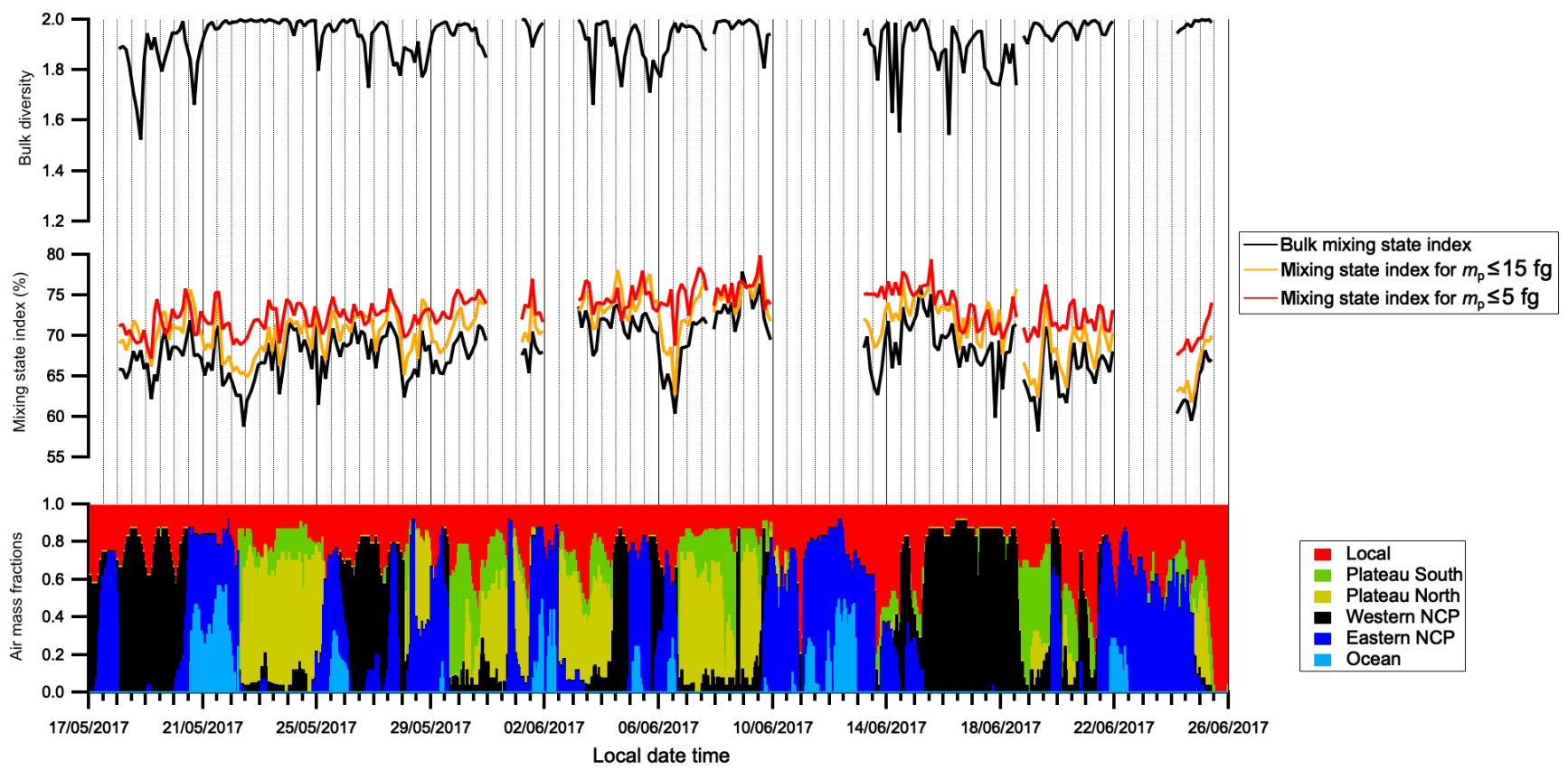

(b)

Figure 10. Bulk diversity and mixing state index for the winter (a) and summer (b).

smaller rBC-containing particles, and the bulk $\chi_{\mathrm{rBC}}$ is generally higher than the winter period for most of the time. This could be through a lower diversity of sources during certain periods and/or a difference in atmospheric processes that leads to a uniform condensation of secondary material without significantly raising $\mathrm{MR}_{\text {bulk. }}$ In summer, the concentrations of primary aerosols are lower compared to winter, and secondary organic aerosols (SOAs) contribute a larger fraction to the total organic aerosols (OAs) in Beijing (Sun et al., 2018; Hu et al., 2016). Previous studies show that an internal mixture would be expected for BC associated with a larger secondary fraction (Krasowsky et al., 2018; Bondy et al., 2018), but the lower overall pollution levels in summer limited the formation of large $\mathrm{rBC}$-containing particles. This may cause the large variation of $\chi_{\mathrm{rBC}}$ in summer.

Results comparing both seasons suggest that the increase in non-rBC material with $\mathrm{MR}_{\text {bulk }}$ above four could lead to a more even distribution of $\mathrm{rBC}$ and non-rBC material 


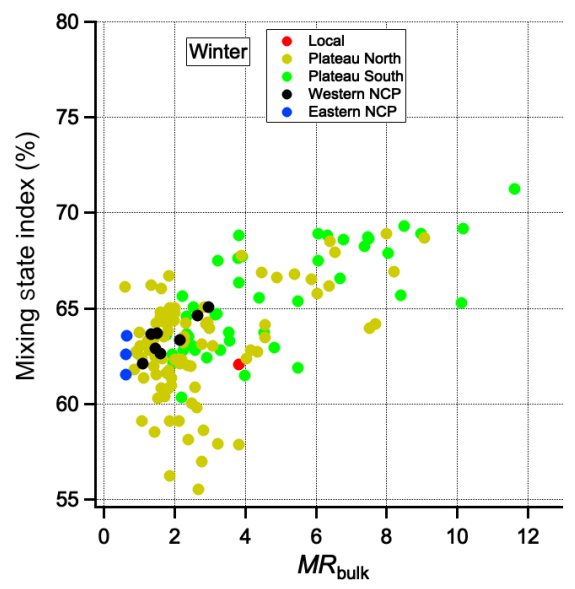

(a)

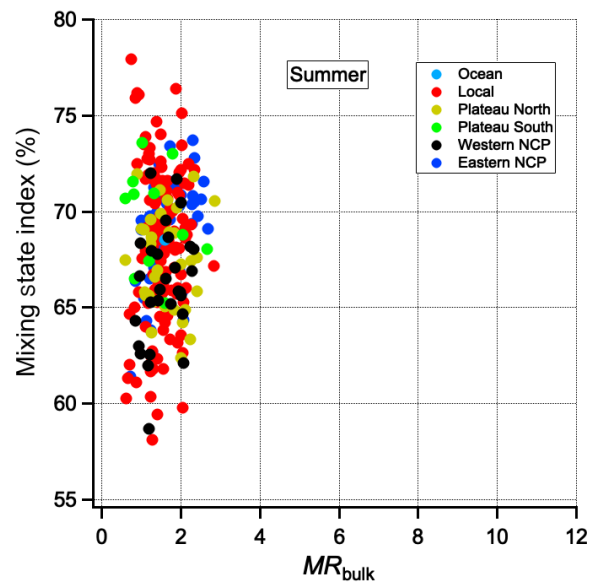

(b)

Figure 11. Air mass sources contribute to the MR and mixing state index for summer (a) and winter (b).

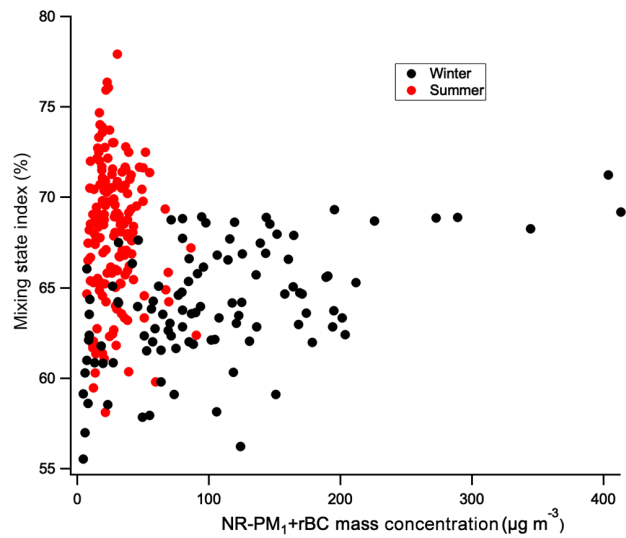

(a)

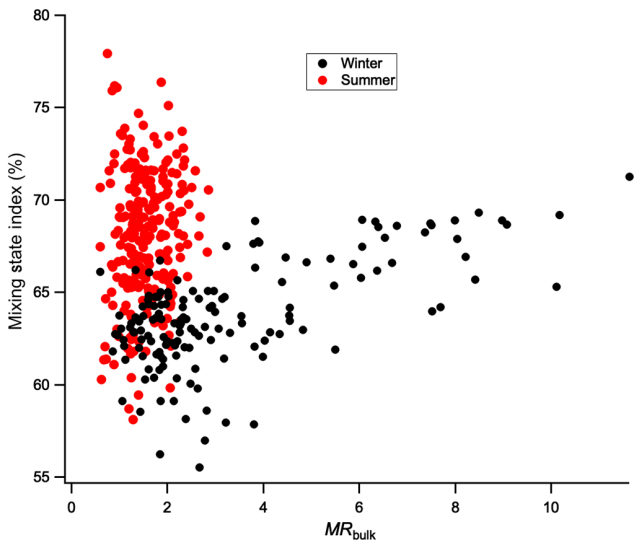

Figure 12. (a) The relationship between NR-PM 1 and $\mathrm{rBC}$ mass concentration and the mixing state index. (b) The relationship between $\mathrm{MR}_{\text {bulk }}$ and the mixing state index.

$\left(\chi_{\mathrm{rBC}}>60 \%\right)$, as indicated by the winter results. In contrast, during summer the $\chi_{\mathrm{rBC}}$ had a larger variation, and an even mixture for $\mathrm{rBC}$-containing particles was still possible when $\mathrm{MR}_{\text {bulk }}$ and the overall pollution level was lower.

\section{Implications for the future studies}

The CPMA-SP2 together with a new inversion method are capable of exploring ambient $\mathrm{BC}$ mixing state in a way not previously possible. The detailed two-variable distribution is able to retrieve the mixing state information on a single-particle level. For future studies, the detailed twovariable distribution results from the CPMA-SP2 can be directly compared with mixing-state-aware models such as GLOMAP (Mann et al., 2010) and the particle-resolved model PartMC-MOSAIC (Riemer et al., 2009) when simulating the behaviour of $\mathrm{BC}$ in polluted plumes. Some mod- elling studies have suggested that large uncertainties of BC atmospheric lifetime result from uncertainties in the scavenging efficiency (e.g. Myhre and Samset, 2015). The processes of activation and impaction scavenging are partly dictated by the overall size and soluble fraction of the rBC-containing particles, which would manifest in the data presented here. However, while some models carry this information (e.g. hydrophobic vs. hydrophilic BC in GLOMAP) this is poorly constrained partly because of the lack of observations that can resolve this (Taylor et al., 2014). In general, more detailed non-rBC material information (MR results) and singleparticle level mixing state information presented in our study can contribute to future studies concerning BC lifetime and transportation to help to constrain the simulations (Bond et al., 2013; Fierce et al., 2017). 


\section{Conclusions}

In this study, the combination of a centrifugal particle mass analyser (CPMA) and a single-particle soot photometer (SP2) has been applied to the investigation of the mixing state of refractory black carbon ( $\mathrm{rBC}$ )-containing particles in urban Beijing. A novel CPMA-SP2 inversion algorithm is able to present the detailed two-variable number distribution as a function of $\mathrm{rBC}$ mass and total rBC-containing-particle mass. As the CPMA-SP2 system directly measures the particle mass, more accurate mass ratio (MR) results for the rBC-containing particles are reported. With the detailed inversion metric results, the mixing state index $\left(\chi_{\mathrm{rBC}}\right)$ is derived to quantify the distribution $\mathrm{rBC}$ and non-rBC material mass fractions within the population of $\mathrm{rBC}$-containing particles. The measurement results show that the measured bulk MR (MR $\left.\mathrm{Mulk}_{\text {buring }}\right)$ durinter campaign period varied significantly from around 2 to 12 , while the $\chi_{\mathrm{rBC}}$ value varied between $55 \%$ and $70 \%$. The highest $\mathrm{MR}_{\text {bulk }}$ values were associated with the haze-polluted periods in winter, and the $\chi_{\mathrm{rBC}}$ value reached higher values under these conditions (over $65 \%$ ), which illustrated there was a more even distribution of $\mathrm{rBC}$ and non-rBC material mass fractions during this period. This result shows that higher pollution levels will increase the non-rBC material in $\mathrm{rBC}$-containing particles and promote a more homogenous distribution of non-rBC material and $\mathrm{rBC}$ material in winter. These results further imply that the $\mathrm{MR}_{\text {bulk }}$ may be a good predictor of $\chi_{\mathrm{rBC}}$ in this season. Meanwhile, the back-trajectory analysis indicates that polluted air from the Southern Plateau dominated the aged $\mathrm{rBC}$-containing particles in Beijing during winter. For the summer campaign period, the $\mathrm{MR}_{\text {bulk }}$ varied between 2 and 3 . The $\chi_{\mathrm{rBC}}$ varied between $60 \%$ and $75 \%$ but was found to be independent of $\mathrm{MR}_{\text {bulk }}$. The slightly higher $\chi_{\mathrm{rBC}}$ in summer indicates a more even distribution of $\mathrm{rBC}$ and nonrBC material mass fractions, which may be caused by higher availability of secondary material. However, a large fraction of non-rBC material within the rBC-containing-particle population (large $\mathrm{MR}_{\text {bulk }}$ ) was not favoured, due to the lack of heavily polluted events in summer, and further no apparent relationship was found between the rBC-containing-particle mixing state and air mass sources. The observations presented here have implications for detailed models of BC, its optical properties and its atmospheric life cycle, which are necessary to assess its local and global impacts. For models that consider mixing state, the methods and results discussed here can better describe the $\mathrm{BC}$ mixing state, which may offer new insights and contribute to improvements in the accuracy of simulations.

Data availability. Processed SP2 data are available through the APHH project archive at the Centre for Environmental Data Analysis (http://data.ceda.ac.uk/badc/aphh/data/beijing/, Yu et al., 2017).
Raw data are archived at the University of Manchester and are available on request.

Supplement. The supplement related to this article is available online at: https://doi.org/10.5194/acp-20-3645-2020-supplement.

Author contributions. DL, JDA and JO designed the research; CY, DL, JDA, R.J., HC, YS and PF performed experiments; KB and JO provided the initial inversion code; $C Y$ adapted the inversion code and performed the CPMA-SP2 data analysis; DL performed the initial SP2 data processing and HYSPLIT runs; YS analysed the NR-PM 1 data; CY, DL and JDA wrote the paper.

Competing interests. The authors declare that they have no conflict of interest.

Special issue statement. This article is part of the special issue "In-depth study of air pollution sources and processes within Beijing and its surrounding region (APHH-Beijing) (ACP/AMT interjournal SI)". It is not associated with a conference.

Financial support. This research has been supported by the UK Natural Environment Research (grant nos. NE/N007123/1 and NE/N00695X/1) and the National Natural Science Foundation of China (grant nos. 41571130024, 41571130034 and 21777073.).

Review statement. This paper was edited by Mei Zheng and reviewed by three anonymous referees.

\section{References}

Adachi, K., Moteki, N., Kondo, Y., and Igarashi, Y.: Mixing states of light-absorbing particles measured using a transmission electron microscope and a single-particle soot photometer in Tokyo, Japan, J. Geophys. Res.-Atmos., 121, 9153-9164, https://doi.org/10.1002/2016jd025153, 2016.

Bond, T. C. and Bergstrom, R. W.: Light Absorption by Carbonaceous Particles: An Investigative Review, Aerosol Sci. Tech., 40, 27-67, https://doi.org/10.1080/02786820500421521, 2006.

Bond, T. C., Doherty, S. J., Fahey, D. W., Forster, P. M., Berntsen, T., DeAngelo, B. J., Flanner, M. G., Ghan, S., Kärcher, B., Koch, D., Kinne, S., Kondo, Y., Quinn, P. K., Sarofim, M. C., Schultz, M. G., Schulz, M., Venkataraman, C., Zhang, H., Zhang, S., Bellouin, N., Guttikunda, S. K., Hopke, P. K., Jacobson, M. Z., Kaiser, J. W., Klimont, Z., Lohmann, U., Schwarz, J. P., Shindell, D., Storelvmo, T., Warren, S. G., and Zender, C. S.: Bounding the role of black carbon in the climate system: A scientific assessment, J. Geophys. Res.-Atmos., 118, 5380-5552, https://doi.org/10.1002/jgrd.50171, 2013.

Bondy, A. L., Bonanno, D., Moffet, R. C., Wang, B., Laskin, A., and Ault, A. P.: The diverse chemical mixing state of 
aerosol particles in the southeastern United States, Atmos. Chem. Phys., 18, 12595-12612, https://doi.org/10.5194/acp-18-125952018, 2018.

Broda, K. N., Olfert, J. S., Irwin, M., Schill, G. P., McMeeking, G. R., Schnitzler, E. G., and Jäger, W.: A novel inversion method to determine the mass distribution of non-refractory coatings on refractory black carbon using a centrifugal particle mass analyzer and single particle soot photometer, Aerosol Sci. Tech., 52, 567578, https://doi.org/10.1080/02786826.2018.1433812, 2018.

Cappa, C. D., Onasch, T. B., Massoli, P., Worsnop, D. R., Bates, T. S., Cross, E. S., Davidovits, P., Hakala, J., Hayden, K. L., and Jobson, B. T.: Radiative absorption enhancements due to the mixing state of atmospheric black carbon, Science, 337, 1078-1081, 2012.

Ching, J. and Kajino, M.: Aerosol mixing state matters for particles deposition in human respiratory system, Sci. Rep.-UK, 8, 8864, https://doi.org/10.1038/s41598-018-27156-z, 2018.

DeCarlo, P. F., Kimmel, J. R., Trimborn, A., Northway, M. J., Jayne, J. T., Aiken, A. C., Gonin, M., Fuhrer, K., Horvath, T., Docherty, K. S., Worsnop, D. R., and Jimenez, J. L.: Field-Deployable, High-Resolution, Time-ofFlight Aerosol Mass Spectrometer, Anal. Chem., 78, 8281-8289, https://doi.org/10.1021/ac061249n, 2006.

Dickau, M., Olfert, J., Stettler, M. E. J., Boies, A., Momenimovahed, A., Thomson, K., Smallwood, G., and Johnson, M.: Methodology for quantifying the volatile mixing state of an aerosol, Aerosol Sci. Tech., 50, 759-772, https://doi.org/10.1080/02786826.2016.1185509, 2016.

Draxler, R. R. and Hess, G. D.: An overview of the HYSPLIT_ 4 modelling system for trajectories, Aust. Meteorol. Mag., 47, 295-308, 1998.

Fierce, L., Bond, T. C., Bauer, S. E., Mena, F., and Riemer, N.: Black carbon absorption at the global scale is affected by particle-scale diversity in composition, Nat. Commun., 7, 12361, https://doi.org/10.1038/ncomms12361, 2016.

Fierce, L., Riemer, N., and Bond, T. C.: Toward Reduced Representation of Mixing State for Simulating Aerosol Effects on Climate, B. Am. Meteorol. Soc., 98, 971-980, 10.1175/bams-d-160028.1, 2017.

Gao, R. S., Schwarz, J. P., Kelly, K. K., Fahey, D. W., Watts, L. A., Thompson, T. L., Spackman, J. R., Slowik, J. G., Cross, E. S., Han, J. H., Davidovits, P., Onasch, T. B., and Worsnop, D. R.: A Novel Method for Estimating LightScattering Properties of Soot Aerosols Using a Modified SingleParticle Soot Photometer, Aerosol Sci. Tech., 41, 125-135, https://doi.org/10.1080/02786820601118398, 2007.

Gong, X., Zhang, C., Chen, H., Nizkorodov, S. A., Chen, J., and Yang, X.: Size distribution and mixing state of black carbon particles during a heavy air pollution episode in Shanghai, Atmos. Chem. Phys., 16, 5399-5411, https://doi.org/10.5194/acp16-5399-2016, 2016.

Healy, R. M., Riemer, N., Wenger, J. C., Murphy, M., West, M., Poulain, L., Wiedensohler, A., O'Connor, I. P., McGillicuddy, E., Sodeau, J. R., and Evans, G. J.: Single particle diversity and mixing state measurements, Atmos. Chem. Phys., 14, 6289-6299, https://doi.org/10.5194/acp-14-6289-2014, 2014.

Hu, W., Hu, M., Hu, W., Jimenez, J. L., Yuan, B., Chen, W., Wang, M., Wu, Y., Chen, C., Wang, Z., Peng, J., Zeng, L., and Shao, M.: Chemical composition, sources, and aging pro- cess of submicron aerosols in Beijing: Contrast between summer and winter, J. Geophys. Res.-Atmos., 121, 1955-1977, https://doi.org/10.1002/2015jd024020, 2016.

IPCC: Annex I: Atlas of Global and Regional Climate Projections in: Climate Change 2013: The Physical Science Basis. Contribution of Working Group I to the Fifth Assessment Report of the Intergovernmental Panel on Climate Change, edited by: Stocker, T. F., Qin, D., Plattner, G.-K., Tignor, M., Allen, S. K., Boschung, J., Nauels, A., Xia, Y., Bex, V., and Midgley, P. M., Cambridge University Press, Cambridge, United Kingdom and New York, NY, USA, 1311-1394, 2013.

Jacobson, M. Z.: A physically-based treatment of elemental carbon optics: Implications for global direct forcing of aerosols, Geophys. Res. Lett., 27, 217-220, https://doi.org/10.1029/1999gl010968, 2000.

Jacobson, M. Z.: Strong radiative heating due to the mixing state of black carbon in atmospheric aerosols, Nature, 409, 695-697, https://doi.org/10.1038/35055518, 2001.

Krasowsky, T. S., McMeeking, G. R., Sioutas, C., and Ban-Weiss, G.: Characterizing the evolution of physical properties and mixing state of black carbon particles: from near a major highway to the broader urban plume in Los Angeles, Atmos. Chem. Phys., 18, 11991-12010, https://doi.org/10.5194/acp-18-119912018, 2018.

Kuwata, M., Kondo, Y., Mochida, M., Takegawa, N., and Kawamura, K.: Dependence of CCN activity of less volatile particles on the amount of coating observed in Tokyo, J. Geophys. Res., 112, D11207, https://doi.org/10.1029/2006jd007758, 2007.

Laborde, M., Mertes, P., Zieger, P., Dommen, J., Baltensperger, U., and Gysel, M.: Sensitivity of the Single Particle Soot Photometer to different black carbon types, Atmos. Meas. Tech., 5, 10311043, https://doi.org/10.5194/amt-5-1031-2012, 2012

Lack, D. A. and Cappa, C. D.: Impact of brown and clear carbon on light absorption enhancement, single scatter albedo and absorption wavelength dependence of black carbon, Atmos. Chem. Phys., 10, 4207-4220, https://doi.org/10.5194/acp10-4207-2010, 2010.

Liu, D., Flynn, M., Gysel, M., Targino, A., Crawford, I., Bower, K., Choularton, T., Jurányi, Z., Steinbacher, M., Hüglin, C., Curtius, J., Kampus, M., Petzold, A., Weingartner, E., Baltensperger, U., and Coe, H.: Single particle characterization of black carbon aerosols at a tropospheric alpine site in Switzerland, Atmos. Chem. Phys., 10, 7389-7407, https://doi.org/10.5194/acp10-7389-2010, 2010.

Liu, D., Allan, J. D., Young, D. E., Coe, H., Beddows, D., Fleming, Z. L., Flynn, M. J., Gallagher, M. W., Harrison, R. M., Lee, J., Prevot, A. S. H., Taylor, J. W., Yin, J., Williams, P. I., and Zotter, P.: Size distribution, mixing state and source apportionment of black carbon aerosol in London during wintertime, Atmos. Chem. Phys., 14, 10061-10084, https://doi.org/10.5194/acp-1410061-2014, 2014.

Liu, D., Quennehen, B., Darbyshire, E., Allan, J. D., Williams, P. I., Taylor, J. W., Bauguitte, S. J.-B., Flynn, M. J., Lowe, D., Gallagher, M. W., Bower, K. N., Choularton, T. W., and Coe, H.: The importance of Asia as a source of black carbon to the European Arctic during springtime 2013, Atmos. Chem. Phys., 15, 11537 11555, https://doi.org/10.5194/acp-15-11537-2015, 2015.

Liu, D., Whitehead, J., Alfarra, M. R., Reyes-Villegas, E., Spracklen, Dominick V., Reddington, C. L., Kong, S., Williams, 
P. I., Ting, Y.-C., Haslett, S., Taylor, J. W., Flynn, M. J., Morgan, W. T., McFiggans, G., Coe, H., and Allan, J. D.: Black-carbon absorption enhancement in the atmosphere determined by particle mixing state, Nat. Geosci., 10, 184-188, https://doi.org/10.1038/ngeo2901, 2017.

Liu, D., Taylor, J. W., Crosier, J., Marsden, N., Bower, K. N., Lloyd, G., Ryder, C. L., Brooke, J. K., Cotton, R., Marenco, F., Blyth, A., Cui, Z., Estelles, V., Gallagher, M., Coe, H., and Choularton, T. W.: Aircraft and ground measurements of dust aerosols over the west African coast in summer 2015 during ICE-D and AER-D, Atmos. Chem. Phys., 18, 3817-3838, https://doi.org/10.5194/acp-18-3817-2018, 2018.

Liu, D., Joshi, R., Wang, J., Yu, C., Allan, J. D., Coe, H., Flynn, M. J., Xie, C., Lee, J., Squires, F., Kotthaus, S., Grimmond, S., Ge, X., Sun, Y., and Fu, P.: Contrasting physical properties of black carbon in urban Beijing between winter and summer, Atmos. Chem. Phys., 19, 6749-6769, https://doi.org/10.5194/acp19-6749-2019, 2019.

Mann, G. W., Carslaw, K. S., Spracklen, D. V., Ridley, D. A., Manktelow, P. T., Chipperfield, M. P., Pickering, S. J., and Johnson, C. E.: Description and evaluation of GLOMAP-mode: a modal global aerosol microphysics model for the UKCA composition-climate model, Geosci. Model Dev., 3, 519-551, https://doi.org/10.5194/gmd-3-519-2010, 2010.

McMeeking, G. R., Hamburger, T., Liu, D., Flynn, M., Morgan, W. T., Northway, M., Highwood, E. J., Krejci, R., Allan, J. D., Minikin, A., and Coe, H.: Black carbon measurements in the boundary layer over western and northern Europe, Atmos. Chem. Phys., 10, 9393-9414, https://doi.org/10.5194/acp10-9393-2010, 2010.

Moffet, R. C. and Prather, K. A.: In-situ measurements of the mixing state and optical properties of soot with implications for radiative forcing estimates, P. Natl. Acad. Sci. USA, 106, 11872 11877, 2009.

Motos, G., Schmale, J., Corbin, J. C., Zanatta, M., Baltensperger, U., and Gysel-Beer, M.: Droplet activation behaviour of atmospheric black carbon particles in fog as a function of their size and mixing state, Atmos. Chem. Phys., 19, 2183-2207, https://doi.org/10.5194/acp-19-2183-2019, 2019.

Murphy, D. M., Cziczo, D. J., Froyd, K. D., Hudson, P. K., Matthew, B. M., Middlebrook, A. M., Peltier, R. E., Sullivan, A., Thomson, D. S., and Weber, R. J.: Single-particle mass spectrometry of tropospheric aerosol particles, J. Geophys. Res.-Atmos., 111, D23S32, https://doi.org/10.1029/2006jd007340, 2006.

Myhre, G. and Samset, B. H.: Standard climate models radiation codes underestimate black carbon radiative forcing, Atmos. Chem. Phys., 15, 2883-2888, https://doi.org/10.5194/acp15-2883-2015, 2015.

Olfert, J. S. and Collings, N.: New method for particle mass classification-the Couette centrifugal particle mass analyzer, J. Aerosol Sci., 36, 1338-1352, https://doi.org/10.1016/j.jaerosci.2005.03.006, 2005.

Olfert, J. S., Reavell, K. S., Rushton, M. G., and Collings, N.: The experimental transfer function of the Couette centrifugal particle mass analyzer, J. Aerosol Sci., 37, 1840-1852, https://doi.org/10.1016/j.jaerosci.2006.07.007, 2006.

Peng, J., Hu, M., Guo, S., Du, Z., Zheng, J., Shang, D., Levy Zamora, M., Zeng, L., Shao, M., Wu, Y.-S., Zheng, J., Wang, Y., Glen, C. R., Collins, D. R., Molina, M. J., and Zhang, R.:
Markedly enhanced absorption and direct radiative forcing of black carbon under polluted urban environments, P. Natl. Acad. Sci. USA, 113, 4266-4271, 2016.

Péré, J. C., Mallet, M., Bessagnet, B., and Pont, V.: Evidence of the aerosol core-shell mixing state over Europe during the heat wave of summer 2003 by using CHIMERE simulations and AERONET inversions, Geophys. Res. Lett., 36, L09807, https://doi.org/10.1029/2009gl037334, 2009.

Petzold, A., Ogren, J. A., Fiebig, M., Laj, P., Li, S.-M., Baltensperger, U., Holzer-Popp, T., Kinne, S., Pappalardo, G., Sugimoto, N., Wehrli, C., Wiedensohler, A., and Zhang, X.-Y.: Recommendations for reporting "black carbon" measurements, Atmos. Chem. Phys., 13, 8365-8379, https://doi.org/10.5194/acp13-8365-2013, 2013.

Ramanathan, V. and Carmichael, G.: Global and regional climate changes due to black carbon, Nat. Geosci., 1, 221-227, https://doi.org/10.1038/ngeo156, 2008.

Riemer, N. and West, M.: Quantifying aerosol mixing state with entropy and diversity measures, Atmos. Chem. Phys., 13, 11423 11439, https://doi.org/10.5194/acp-13-11423-2013, 2013.

Riemer, N., West, M., Zaveri, R. A., and Easter, R. C.: Simulating the evolution of soot mixing state with a particle-resolved aerosol model, J. Geophys. Res., 114, https://doi.org/10.1029/2008jd011073, 2009.

Riemer, N., Ault, A. P., West, M., Craig, R. L., and Curtis, J. H.: Aerosol Mixing State: Measurements, Modeling, and Impacts, Rev. Geophys., 57, 187-249, https://doi.org/10.1029/2018RG000615, 2019.

Schroder, J. C., Hanna, S. J., Modini, R. L., Corrigan, A. L., Kreidenwies, S. M., Macdonald, A. M., Noone, K. J., Russell, L. M., Leaitch, W. R., and Bertram, A. K.: Size-resolved observations of refractory black carbon particles in cloud droplets at a marine boundary layer site, Atmos. Chem. Phys., 15, 1367-1383, https://doi.org/10.5194/acp-15-1367-2015, 2015.

Schwarz, J. P., Spackman, J. R., Gao, R. S., Perring, A. E., Cross, E., Onasch, T. B., Ahern, A., Wrobel, W., Davidovits, P., Olfert, J., Dubey, M. K., Mazzoleni, C., and Fahey, D. W.: The Detection Efficiency of the Single Particle Soot Photometer, Aerosol Sci. Tech., 44, 612-628, https://doi.org/10.1080/02786826.2010.481298, 2010.

Shannon, C. E.: A mathematical theory of communication, SIGMOBILE Mob. Comput. Commun. Rev., 5, 3-55, https://doi.org/10.1145/584091.584093, 2001.

Shi, Z., Vu, T., Kotthaus, S., Harrison, R. M., Grimmond, S., Yue, S., Zhu, T., Lee, J., Han, Y., Demuzere, M., Dunmore, R. E., Ren, L., Liu, D., Wang, Y., Wild, O., Allan, J., Acton, W. J., Barlow, J., Barratt, B., Beddows, D., Bloss, W. J., Calzolai, G., Carruthers, D., Carslaw, D. C., Chan, Q., Chatzidiakou, L., Chen, Y., Crilley, L., Coe, H., Dai, T., Doherty, R., Duan, F., Fu, P., Ge, B., Ge, M., Guan, D., Hamilton, J. F., He, K., Heal, M., Heard, D., Hewitt, C. N., Hollaway, M., Hu, M., Ji, D., Jiang, X., Jones, R., Kalberer, M., Kelly, F. J., Kramer, L., Langford, B., Lin, C., Lewis, A. C., Li, J., Li, W., Liu, H., Liu, J., Loh, M., Lu, K., Lucarelli, F., Mann, G., McFiggans, G., Miller, M. R., Mills, G., Monk, P., Nemitz, E., O'Connor, F., Ouyang, B., Palmer, P. I., Percival, C., Popoola, O., Reeves, C., Rickard, A. R., Shao, L., Shi, G., Spracklen, D., Stevenson, D., Sun, Y., Sun, Z., Tao, S., Tong, S., Wang, Q., Wang, W., Wang, X., Wang, X., Wang, Z., Wei, L., Whalley, L., Wu, X., Wu, Z., Xie, P., Yang, F., Zhang, 
Q., Zhang, Y., Zhang, Y., and Zheng, M.: Introduction to the special issue "In-depth study of air pollution sources and processes within Beijing and its surrounding region (APHH-Beijing)", Atmos. Chem. Phys., 19, 7519-7546, https://doi.org/10.5194/acp19-7519-2019, 2019.

Stephens, M., Turner, N., and Sandberg, J.: Particle identification by laser-induced incandescence in a solid-state laser cavity, Appl. Optics, 42, 3726-3736, https://doi.org/10.1364/AO.42.003726, 2003.

Sun, Y., Xu, W., Zhang, Q., Jiang, Q., Canonaco, F., Prévôt, A. S. H., Fu, P., Li, J., Jayne, J., Worsnop, D. R., and Wang, Z.: Source apportionment of organic aerosol from 2-year highly time-resolved measurements by an aerosol chemical speciation monitor in Beijing, China, Atmos. Chem. Phys., 18, 8469-8489, https://doi.org/10.5194/acp-18-8469-2018, 2018.

Taylor, J. W., Allan, J. D., Allen, G., Coe, H., Williams, P. I., Flynn, M. J., Le Breton, M., Muller, J. B. A., Percival, C. J., Oram, D., Forster, G., Lee, J. D., Rickard, A. R., Parrington, M., and Palmer, P. I.: Size-dependent wet removal of black carbon in Canadian biomass burning plumes, Atmos. Chem. Phys., 14, 13755-13771, https://doi.org/10.5194/acp-14-137552014, 2014.

Wang, J., Liu, D., Ge, X., Wu, Y., Shen, F., Chen, M., Zhao, J., Xie, C., Wang, Q., Xu, W., Zhang, J., Hu, J., Allan, J., Joshi, R., $\mathrm{Fu}, \mathrm{P}$., Coe, H., and Sun, Y.: Characterization of black carboncontaining fine particles in Beijing during wintertime, Atmos. Chem. Phys., 19, 447-458, https://doi.org/10.5194/acp-19-4472019, 2019.

Whittaker, R. H.: Vegetation of the Siskiyou Mountains, Oregon and California, Ecol. Monogr., 30, 279-338, https://doi.org/10.2307/1943563, 1960.

Whittaker, R. H.: Dominance and Diversity in Land Plant Communities, Science, 147, 250-260, 1965.
Wu, Y., Wang, X., Tao, J., Huang, R., Tian, P., Cao, J., Zhang, L., Ho, K.-F., Han, Z., and Zhang, R.: Size distribution and source of black carbon aerosol in urban Beijing during winter haze episodes, Atmos. Chem. Phys., 17, 7965-7975, https://doi.org/10.5194/acp-17-7965-2017, 2017.

Wu, Y., Cheng, T., Liu, D., Allan, J. D., Zheng, L., and Chen, H.: Light Absorption Enhancement of Black Carbon Aerosol Constrained by Particle Morphology, Environ. Sci. Technol., 52, 6912-6919, https://doi.org/10.1021/acs.est.8b00636, 2018.

Xie, C., Xu, W., Wang, J., Liu, D., Ge, X., Zhang, Q., Wang, Q., Du, W., Zhao, J., Zhou, W., Li, J., Fu, P., Wang, Z., Worsnop, D., and Sun, Y.: Light absorption enhancement of black carbon in urban Beijing in summer, Atmos. Environ., 213, 499-504, https://doi.org/10.1016/j.atmosenv.2019.06.041, 2019.

Yang, J., McBride, J., Zhou, J., and Sun, Z.: The urban forest in Beijing and its role in air pollution reduction, Urban For. Urban Green., 3, 65-78, https://doi.org/10.1016/j.ufug.2004.09.001, 2005.

Yu, C., Liu, D., and Allan, J.: APHH: Atmospheric measurements and model results for the Atmospheric Pollution \& Human Health in a Chinese Megacity, available at: http://data.ceda.ac. uk/badc/aphh/data/beijing/, last access: 18 October 2017.

Zhang, X., Mao, M., Yin, Y., and Wang, B.: Numerical Investigation on Absorption Enhancement of Black Carbon Aerosols Partially Coated With Nonabsorbing Organics, J. Geophys. Res.-Atmos., 123, 1297-1308, https://doi.org/10.1002/2017JD027833, 2018a.

Zhang, Y., Zhang, Q., Cheng, Y., Su, H., Li, H., Li, M., Zhang, X., Ding, A., and He, K.: Amplification of light absorption of black carbon associated with air pollution, Atmos. Chem. Phys., 18, 9879-9896, https://doi.org/10.5194/acp-18-9879-2018, 2018b. 